\title{
ANALISIS PERILAKU INSTABILITAS, PERGERAKAN HARGA, EMPLOYMENT DAN INVESTASI DI DALAM SEKTOR PERTANIAN INDONESIA: Aplikasi Vector Error Correction Model ${ }^{1}$
}

\author{
Andi Irawan ${ }^{2}$
}

\begin{abstract}
In a long run perspective, the aim of this research is to analyze the impact of the inflating-policy on the employment growth, and the agriculture investment. From a short run perspective, the aim covers (1) the identification of agriculture price instability on certain economic blocks, (2) the analysis of inflation behavior in the agriculture sector and its causality both to output price and input prices and the causality within the input prices.

We apply the Vector Error Correction Model, Johansen Cointegration Test, and Granger Causality Test on a monthly series data from 1993:01 to 2002:12. The result shows the production and capital in agriculture sector are responsive to the output price change. This mean inflating the output price will effectively help to generate the output and a new investment in this sector. However, as the price shock can be a source of instability, the government should be careful to apply this price inflating policy. In addition, to solve the unemployment problem in agriculture sector, the government should apply the cost strategy, such as input price subsidy policy.
\end{abstract}

JEL: C32, C52, 013, Q11, Q18

Keyword: Employment, Investasi, Agriculture,Johansen, Cointegration Vector Error Correction Model, Causality Test

\footnotetext{
1 Tulisan ini merupakan bagian dari disertasi doktor (S3) penulis pada program studi Ilmu Ekonomi Pertanian IPB yang berjudul Analisis Keterkaitan Ekonomi Makro, Perdagangan Internasional dan Sektor Pertanian di Indonesia: Aplikasi Vector Error Correction Model. 2 Penulis adalah Staf Pengajar pada Universitas Bengkulu.
} 


\section{PENDAHULUAN}

\section{I.1. Latar Belakang}

Peran sektor pertanian tetap penting dalam dalam persepektif ekonomi makro. Pertama, sektor pertanian merupakan sumber pertumbuhan output nasional yang penting, studi Herliana (2004) menunjukkan sektor ini memberikan kontribusi 19.1 \% terhadap PDB dari keseluruhan sektor perekonomian Indonesia. Walaupun secara absolut lebih kecil jika dibanding dengan kontribusi sektor jasa (43.5 persen) dan manufaktur (23.9 persen) namun sektor pertanian merupakan penyerap tenaga kerja terbesar yakni 47.1 persen. Tidak mengherankan kalau sejumlah kajian masih merekomendasikan agar investasi pemerintah tetap diprioritaskan ditanam dalam sektor ini (lihat antara lain Syafa'at dan Mardianto (2002) dan Hutabarat (2001).

Kedua, sektor pertanian memiliki karakteristik yang spesifik khususnya dalam hal ketahanan sektor ini terhadap guncangan struktural dari perekonomian makro (Simatupang dan Dermoredjo, 2003). Hal ini ditunjukkan oleh fenomena dimana sektor ini tetap mampu tumbuh positif pada saat puncak krisis ekonomi sementara sektor ekonomi lainnya mengalami kontraksi. Saat krisis pada kondisi parah yang ditunjukkan dengan pertumbuhan PDB negatif yakni sepanjang triwulan pertama 1998 sampai triwulan pertama 1999, tampak bahwa sektor pertanian tetap bisa tumbuh dimana pada triwulan 1 dan triwulan 3 tahun 1998 pertumbuhan sektor pertanian masing-masing adalah 11. 2 persen, sedangkan pada triwulan 1 tahun 1999 tumbuh 17.5 persen. Adapun umumnya sektor non pertanian pada periode krisis ekonomi yang parah tersebut pertumbuhannya adalah negatif (Irawan, 2004).

Melihat arti penting sektor pertanian tersebut diharapkan kebijakan-kebijakan ekonomi negara berupa kebijakan fiskal, kebijakan moneter, dan kebijakan perdagangan, tidak mengabaikan sektor pertanian dalam arti kebijakan-kebijakan tersebut tidak bias kota yakni memperioritaskan aktivitas ekonomi kota yang biasanya digeluti para pelaku ekonomi skala besar, dan juga tidak bias modal dalam arti kebijakan yang berorientasi mendukung para pemiliki modal besar padahal sektor pertanian umumnya digeluti oleh mereka yang dikategorikan sebagai pemodal kecil dan sedang. Untuk itu sangat penting untuk diketahui bagaimana dampak berbagai guncangan eksternal dari luar sektor pertanian terhadap perilaku variabel-variabel ekonomi penting dari sektor pertanian (output atau PDB pertanian, tenaga kerja, inflasi, output, input dan investasi). 


\section{I.2. Tujuan Penelitian}

Adapun tujuan khusus penelitian ini adalah: Pertama, dalam persepektif jangka panjang adalah untuk menganalisis dampak kebijakan yang berakibat kenaikan harga pertanian terhadap pertumbuhan, penyerapan kerja (employment) dan investasi di sektor pertanian.

Kedua dalam jangka pendek (1) menganalisis sektor atau blok ekonomi yang menjadi sumber instabilitas utama bagi sektor pertanian Indonesia, (2) Menganalisis perilaku pergerakan harga output pertanian (inflasi) dan kausalitas antara harga output dan harga input, serta kausalitas antar harga-harga input penting.

\section{KERANGKA PEMIKIRAN}

\section{II.1. Struktur Dasar Model}

Model di dalam penelitian mengadopsi model Sugema-In (model-SI). Ekonomi di dalam model mencakup dua negara, yakni ekonomi domestik dan ekonomi luar negeri. Masingmasing negara memperoduksi dua komoditas, komoditas pertanian (A) dan non-pertanian $(\mathrm{N})$. Agen-agen ekonomi dibagi menjadi tiga group, konsumen, produser dan pemerintah. Input yang digunakan dalam produksi juga terdiri atas tiga komponen yakni tenaga kerja (L), modal (K), dan material (m). Ada empat pasar, yakni pasar komoditas, pasar input, pasar finansial dan pasar internasional (pasar ekspor).

Konsumen diasumsikan memaksimumkan utilitas total waktu hidup mereka (total lifetime utility) dengan kendala keadaan anggaran mereka (budget constraint), sedangkan produser memaksimumkan arus kas bersih masa depan sampai horison waktu yang tak terbatas (infinite future net cash flow) dengan kendala biaya dari penyesuaian teknologi (adjustment of technology). Perilaku pemerintah dianggap ditentukan secara eksogen dalam arti bahwa perilaku tersebut bukan hasil dari perilaku optimasi secara eksplisit seperti halnya perilaku konsumen dan produser. Pemerintah bertanggung jawab atas kebijakan fiskal, pajak, upah, dan moneter, dimana kebijakan-kebijakan dalam model tersebut diperlakukan sebagai exogenous shock.

Struktur ekonomi ditentukan oleh permintaan dan penawaran dari dua stok aset (asset stocks) dan empat variabel flow. Aset stok adalah uang dan equities (saham). Variabel flow adalah dua komoditas, saham-saham baru (new equities), investasi baru. Di Pasar komoditas baik konsumen dan produser adalah penerima harga. Konsumen bertindak sebagai pembeli dan produser bertindak sebagai penjual untuk komoditas-komoditas tersebut. 
Di dalam pasar finansial produser dan pemerintah mengeluarkan dan membeli suratsurat berharga baru (new bonds). Tujuan mengeluarkan surat berharga (issuing new bonds) adalah untuk mendanai investasi-investasi baru dan defisit anggaran belanja pemerintah. Di pasar input, rumahtangga memiliki dan menjual tenaga kerja mereka sedangkan produser membeli jasa tenaga kerja tersebut. Tingkat upah ditentukan oleh penawaran dan permintaan di pasar; namun pemerintah dapat mempengaruhi pasar dengan mengatur kebijakan upah seperti tingkat upah minimum. Material dan input lain $(\mathrm{m})$ diperlakukan sebagai barang antara (intermediate goods) sehingga baik rumahtangga dan produser dapat memiliki input tersebut.

\section{II.2. Perilaku Perusahaan}

Di dalam pasar komoditas ada dua produser yang menghasilkan dua komoditas berbeda. Pertama, adalah perusahaan pertanian (farm) yang menghasilkan komoditas pertanian. Kedua adalah perusahaan non pertanian. Kalkulasi dari produk nasional yang didasarkan pada metode nilai tambah (value added method) sehingga kontribusi dari masing-masing industri (pertanian dan non pertanian) terhadap produk final dapat dikalkulasi.

Dua industri (produser) tersebut menggunakan tiga input didalam proses produksi mereka yakni; tenaga kerja (L), modal (C), dan material (m). Material didefinisikan sebagai setiap barang (benda) yang digunakan dalam produksi selain tenaga kerja dan modal. la dapat berbentuk bahan baku (raw material) atau semi finished goods. Dimasukkannya material didalam fungsi produksi didasarkan dari teori makro ekonomi tradisional, dimana hanya ada dua input yakni modal dan tenaga kerja. Namun karena teori ekonomi mikro menyatakan bahwa input produksi tidak hanya modal dan tenaga kerja, maka input dalam fungsi produksi di perluas dengan memasukkan input lain. Sebagai contoh, petani menggunakan pupuk dan pestisida di dalam memproduksi komoditas pertanian. Di ketegorikannya input menjadi tiga (tenaga kerja, modal dan material) bukan dua (tenaga kerja dan modal saja), akan membantu mengliminasi kesalahan spesifikasi model.

Perilaku perusahaan (firm) ditentukan oleh tujuannya yang memaksimisasi nilai sekarang dari keuntungannya (present value of the profit). Masing-masing industri ditunjukkan dengan satu fungsi keuntungan tunggal (one single profit function). Berdasarkan perilaku maksimisasi ini produser menentukan rencana produksi dan rencana penggunaan input produksinya pada kondisi harga output, harga input dan tingkat teknologi tertentu. Dengan demikian solusi (hasil) dari perilaku maksimisasi tidak hanya memberikan informasi tentang fungsi respon penawaran tetapi juga fungsi permintaan input seperti permintaan modal, permintaan tenaga kerja, dan permintaan material. 
Produser mendapatkan input modal dari pasar aset (assets market). Harga dari modal merefleksikan tambahan keuntungan yang diharapkan (expected increment of profit) produser untuk satu satuan tambahan stok modal perusahaan. la juga menunjukkan klaim (claims) dari rumah tangga akan bagian yang mereka investasikan di perusahaan. Interpretasi harga modal ini adalah keterkaitan yang kritikal antara keputusan investor dan harga yang terbentuk di pasar akan klaim finansial.

Perusahaan mendapatkan tenaga kerja dan material dari pasar input. Keterkaitan antara pasar output dan pasar input, atau lebih spesifik lagi keterkaitan antara harga output (inflasi) dan employment (atau unemployment) dapat ditemukan dari duality antara fungsi biaya dan produksi. Seseorang dapat menemukan sumber unemployment (pengangguran), apakah karena disebabkan berkurang (melemahnya) permintaan atau karena kurangnya daya saingnya (competitiveness), sebagai contoh karena meningkatnya biaya produksi. la juga memberikan informasi akan sumber inflasi, apakah karena cost push inflation atau demand full inflation.

Anggap suatu fungsi keuntungan tunggal dari produser ke-i, dimana $i=A, N(A=$ industri pertanian, $\mathrm{N}=$ industri non pertanian)

$$
\begin{array}{ll}
\mathrm{V}\left(\mathrm{K}_{\mathrm{i}}, \mathrm{L}_{\mathrm{i}}, \mathrm{m}_{\mathrm{i}}, \mathrm{K}_{\mathrm{i}}, \mathrm{t}\right)= & \int_{0}^{\infty} \mathrm{e}^{-\rho(\mathrm{t})}\left[\mathrm{P}_{\mathrm{i}} \mathrm{F}_{\mathrm{i}}\left(\mathrm{K}_{\mathrm{i}}, \mathrm{L}_{\mathrm{i}}, \mathrm{m}_{\mathrm{i}}\right)-\mathrm{wL}_{\mathrm{i}}-\mathrm{P}_{\mathrm{mi}} \mathrm{m}_{\mathrm{i}}-\right. \\
& \left.\mathrm{P}_{\mathrm{i}}\left(\kappa_{\mathrm{i}}^{\prime}+\delta \mathrm{K}_{\mathrm{i}}\right)\right] \\
\text { dimana: } \quad \rho(\mathrm{t}) \quad= & \int_{0}^{\infty} \mathrm{r}(\mathrm{s}) \mathrm{ds}
\end{array}
$$

Komponen-komponen fungsi keuntungan dapat di deskripsikan sebagai berikut: Pertama, $P_{i} F_{i}\left(K_{i}, L_{i}, m_{i}\right)$ adalah total penerimaan (total revenue) dari produser ke i. Kedua, $\mathrm{WL}$ adalah biaya tenaga kerja yang didefinisikan dari tingkat upah (wage rate) kali jumlah tenaga kerja (employment). Ketiga, $\mathrm{P}_{m i} \mathrm{~m}_{\mathrm{i}}$ adalah biaya material. Terakhir, $\mathrm{P}_{\mathrm{i}}\left(\kappa_{\mathrm{i}}^{\prime}+\delta \mathrm{K}_{\mathrm{i}}\right)$ adalah biaya modal (capital cost) dimana $\mathrm{P}_{\mathrm{k}}$ adalah harga dari modal, $\mathrm{K}_{\mathrm{i}}$ adalah aliran investasi baru (flow of new investment) dan $\delta$ adalah tingkat depresiasi modal.

Fungsi produksi, $\mathrm{F}_{\mathrm{i}}\left(\mathrm{K}_{\mathrm{i}}, \mathrm{L}_{\mathrm{i}}, \mathrm{m}_{\mathrm{i}}\right)$ diasumsikan memiliki semua sifat-sifat neoklasikal standar tentang diferensiabilitas dan konkavitas (differentiability and concavity). Ini mengimplikasikan bahwa produk marginal modal, tenaga kerja, dan material adalah bernilai positif sedangkan derivatif dari produk marginal adalah negatif. Namun produk marginal untuk investasi baru adalah negatif. Kondisi ini secara matematika dapat diekspresikan sebagai berikut: 


$$
\mathrm{F}_{\mathrm{i}}{ }^{\prime}>0, \mathrm{~F}_{\mathrm{i}}{ }^{\prime}<0 \text { dan } \mathrm{F}_{\mathrm{Ki}}<0
$$

Derivasi lengkap dari perilaku maksimisasi dapat dilihat pada lampiran 2. Secara ringkas, first order condition untuk optimalitasnya adalah:

$$
\begin{aligned}
\partial \mathrm{F} / \partial \mathrm{L}_{\mathrm{i}} & =\mathrm{W} / \mathrm{P}_{\mathrm{I}} \\
\partial \mathrm{F} / \partial \mathrm{m}_{\mathrm{i}} & =\mathrm{P}_{\mathrm{mi}} / \mathrm{P}_{\mathrm{I}} \\
\partial \mathrm{F} / \partial \mathrm{K}_{\mathrm{i}} & =\mathrm{P}_{\mathrm{K}} / \mathrm{P}_{\mathrm{I}}\left[\mathrm{r}+\delta-\left(\mathrm{P}_{\mathrm{K}} / \mathrm{P}_{\mathrm{K}}\right)\right]
\end{aligned}
$$

Ada sejumlah implikasi yang dapat ditarik dari kondisi optimal di atas. Pertama, perusahaan harus menyamakan produk marginalnya dengan masing-masing harga. Persamaan (IV.3) menunjukkan produk marginal dari tenaga kerja harus sama dengan tingkat upah. Persamaan (IV.4) menunjukkan produk marginal dari material harus sama dengan harga material. Persamaan (IV.5) mengindikasikan bahwa produk marginal capital harus sama dengan biaya untuk memperoleh modal tersebut, komponen $\mathrm{P}_{\mathrm{K}}\left[\mathrm{r}+\delta-\left(\mathrm{P}_{\mathrm{K}}{ } / \mathrm{P}_{\mathrm{K}}\right)\right]$ atau disederhanakan dengan simbol pk adalah rate nominal dari biaya modal (nominal rate of capital cost), sehingga nilai riilnya adalah $\mathrm{pk} / \mathrm{P}_{\mathrm{i}}$ Kedua, perusahaan harus mengalokasikan anggaran untuk ketiga input secara proporsional berkenaan dengan harga nya masing-masing. Terakhir, akan melakukan penambahan tenaga kerja, modal dan material sepanjang produk marginal dari tenaga kerja, modal dan meterial lebih besar dari harga input-input tersebut. Ini menunjukkan permintaan input adalah fungsi yang berkemiringan negatif.

Hasil akhir dari proses derivasi dari perilaku maksimisasi keuntungan ini, akan diperoleh fungsi berikut:

Permintaan untuk tenaga kerja:

$$
\mathrm{L}_{\mathrm{i}} \quad=\quad f_{\mathrm{Li}}\left\{\mathrm{pk} / \mathrm{P}_{\mathrm{i}}, \mathrm{w}_{\mathrm{i}} / \mathrm{P}_{\mathrm{i}}, \mathrm{P}_{\mathrm{m}} / \mathrm{P}_{\mathrm{i}}, \mathrm{P}_{\mathrm{i}}\right\}
$$

Permintaan untuk modal:

$$
\mathrm{K}_{\mathrm{i}}=f_{\mathrm{Ki}}\left\{\mathrm{pk} / \mathrm{P}_{\mathrm{i}}, \mathrm{W}_{\mathrm{i}} / \mathrm{P}_{\mathrm{i}}, \mathrm{P}_{\mathrm{m}} / \mathrm{P}_{\mathrm{i}}, \mathrm{P}_{\mathrm{i}}\right\}
$$

\section{II.3. Model Konsumsi}

Tujuan dari rumah tangga adalah memaksimisasikan utilitas selama total waktu hidup mereka (its total lifetime utility) dengan kendala ketersediaan anggaran antar waktu (intertemporal budget constraint). Peran rumahtangga dalam perekonomian adalah membuat rencana dan keputusan yang berkaitan dengan konsumsi saat ini (present) dan yang akan datang (future) serta pemegangan aset (assets holdings). Diasumsikan bahwa utilitas 
direpresentasikan dengan fungsi utilitas tunggal (single utiliity function). Fungsi konsumsi dan permintaan aset yang mana berasal dari masalah maksimisasi rumahtangga menunjukkan arti penting dari kekayaan (wealth) dan ekspetasi dari harga aset di masa depan (future asset prices) serta suku bunga sebagai penentu dari perilaku rumahtangga. Rencana rumahtangga sekarang (current plans) melahirkan permintaan konsumsi, money, saham (equities) dan leisure. Dengan demikian fungsi utilitas terdiri dari leisure, barang-barang konsumsi, pemegangan aset (asset holding). Dengan demikian dalam penelitian ini variabel-variabel yang masuk dalam fungsi utilitas adalah:

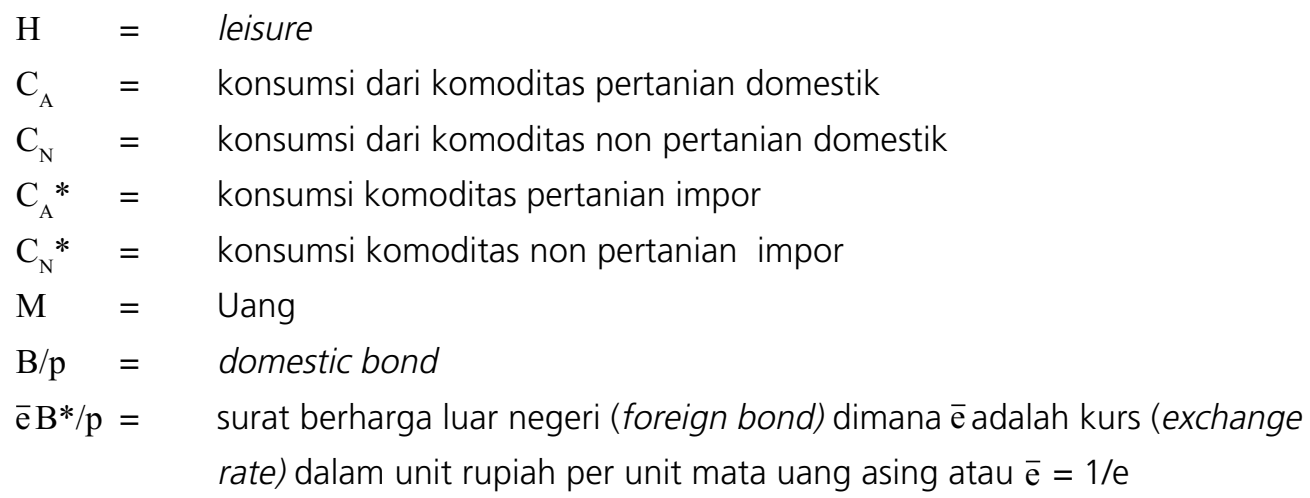

Utilitas pada waktu ke-t dihitung dalam nilai kininya (present value) dengan menggunakan discount rate. Semua variabel diukur dalam nilai riil dan dengan demikian diasumsikan discount ratenya konstan. Aset muncul dalam fungsi utilitas karena dua alasan. Pertama, aset adalah suatu medium yang dapat mempertukarkan konsumsi saat ini dengan konsumsi yang akan datang. Kedua, aset berguna untuk menjamin konsumsi dalam keadaan yang tak bisa di ekspetasi (unexpected shocks). Namun untuk penyederhanaan, perilaku di bawah keadaan yang bersifat uncertainty tidak dikaji dalam penelitian ini.

Fungsi utilitas lifetime dapat dinyatakan sebagai berikut:

$$
\mathrm{V}=\quad \int_{0}^{\infty} \mathrm{e}^{-\mathrm{st}} \mathrm{U}\left(\mathrm{H}, \mathrm{C}_{\mathrm{A}}, \mathrm{C}_{\mathrm{N}}, \mathrm{C}^{*}{ }_{\mathrm{A}}, \mathrm{C}_{\mathrm{N}}{ }^{*}, \mathrm{M} / \mathrm{P}, \mathrm{B} / \mathrm{P}, \overline{\mathrm{e}} \mathrm{B} / \mathrm{p}\right) \mathrm{dt}
$$

Agar dapat lebih mempermudah, maka fungsi utilitas pada setiap waktu U(.) diasumsikan homogen, positif, dan memenuhi hukum kenaikan utilitas marginal yang semakin berkurang setiap kenaikan kuantitas yang dikonsumsi. Dengan demikian turunan pertama dari U(.) akan positif dan turunan kedua dari fungsi tersebut adalah negatif. Perilaku maksimisasi utilitas rumahtangga dihadapkan pada kendala yakni dua sumber pendapatan rumahtangga yakni penghasilan dari aset dan upah yang diharapkan. Penghasilan aset (assets earnings) berasal dari imbalan bunga dari memegang saham domestik $(r B)$ dan dari saham asing ( $\bar{r}{ }^{*} B^{*}$ ), dimana r menunjukkan suku bunga pasar. Upah (wage income) didefinisikan sebagai tingkat upah (w) 
dikalikan total waktu yang dikeluarkan untuk bekerja (L). Pendapatan (income) dialokasikan untuk konsumsi barang pada harga domestik ( $\mathrm{Pi}$ ) dan harga luar negeri ( $\mathrm{Pi}{ }^{\star}$ ) tertentu (given), Permintaan sekarang akan uang (current demand for money) (M), permintaan untuk surat berharga domestik $(B)$ dan surat berharga asing $\left(B^{*}\right)$. Subskrip i menunjuk dua komoditas (A dan $N$ ).

Sedangkan Kendala anggaran dapat dinyatakan sebagai berikut:

$$
\mathrm{P}_{\mathrm{A}} \mathrm{C}_{\mathrm{A}}+\mathrm{P}_{\mathrm{N}} \mathrm{C}_{\mathrm{N}}+\overline{\mathrm{e}}\left(\mathrm{P}_{\mathrm{A}} * \mathrm{C}_{\mathrm{A}} *+\mathrm{P}^{*}{ }_{\mathrm{N}} \mathrm{C}^{*}{ }_{\mathrm{N}}+\mathrm{B} *\right)+\mathrm{M}+\mathrm{B}=\mathrm{wL}+\mathrm{rB}+\overline{\mathrm{e}}{ }^{*} \mathrm{~B} *
$$

Pada kendala anggaran dan fungsi utilitas tertentu dapat diturunkan kondisi optimal sebagai berikut:

$$
\partial \mathrm{U}(.) / \partial \mathrm{X}_{\mathrm{i}} \quad=\quad \lambda \mathrm{P}_{\mathrm{i}}
$$

Kondisi di atas (persamaan IV.10) menyatakan bahwa utilitas optimum dapat dicapai dengan menyamakan utilitas marginal barang dan aset yang dikonsumsi dengan harga mereka. Variabel $\lambda$ dapat dinterpretasikan sebagai shadow price dari penggunaan income untuk belanja tertentu (particular expenditure). Proses rinci penurunan perilaku maksimisasi utilitas rumahtangga dapat dilihat dalam lampiran IV.3. Kondisi di atas berimplikasi bahwa rumahtangga harus mengalokasikan pendapatan mereka untuk konsumsi barang dan aset secara proporsional sesuai dengan harga dan utilitas marginalnya. Selanjutnya konsumsi sepanjang hidup (lifetime consumption) tidak boleh melebihi pendapatan sepanjang hidup (lifetime income), kalau terjadi maka itu berimplikasi defisit konsumen (consumer's deficit). defisit konsumen tidak boleh melebihi kemampuan mereka membayarnya.

Langkah selanjutnya adalah menurunkan harga implisit (implicit price) untuk leisure, uang, surat berharga (bonds), didasarkan pada kondisi di atas, sehingga dapat dinyatakan sebagai berikut:

$$
\begin{array}{ll}
\mathrm{P}_{\mathrm{H}}=\mathrm{W} & \text { harga implicit untuk leisure } \\
\mathrm{P}_{\mathrm{M}}=\mathrm{P}[\mathrm{s}-(-\pi)] & \text { harga implisit untuk pemegangan uang } \\
\mathrm{P}_{\mathrm{B}}=\mathrm{P}[\mathrm{s}-(\mathrm{r}-\pi)] & \text { harga implisit untuk domestic bonds } \\
\mathrm{P}_{\mathrm{B}}^{*}=\mathrm{P}\left[\mathrm{s}-\left(\mathrm{r}^{*}-\pi+\dot{\mathrm{e}} / \overline{\mathrm{e}}\right)\right] \text { harga implisit untuk foreign bond }
\end{array}
$$

Dimana $\mathrm{p}$ dan $\pi$ ukuran tingkat inflasi dan $r$ adalah suku bunga. Persamaan (IV.11) mengukur biaya oportunitas (opportunity cost) dari leisure dan kehilangan income (income losses ) sebagai akibat pemutusan hubungan kerja (PHK), ringkasnya harga dari leisure sama dengan tingkat upah. Persamaan (IV.12) menunjukkan opportunity cost dari memegang uang yang mana berhubungan positif dengan tingkat inflasi. Persamaan (IV.13) dan (IV.14) adalah biaya dari memegang surat berharga (bonds) yang berhubungan positif dengan tingkat inflasi dan berhubungan negatif dengan suku bunga. Dengan demikian tingkat penerimaan riil 
(real rate return) dari memegang surat berharga adalah selisih antara suku bunga dan tingkat inflasi.

Dari penjelasan di atas dapat disimpulkan bahwa permintaan untuk komoditas, aset dan leisure adalah fungsi dari semua harga-harga dari ketiganya. Dengan demikian dapat dirumuskan fungsi permintaan sebagai berikut:

Permintaan optimal untuk komoditas domestik ke-i

$$
\mathrm{C}_{\mathrm{i}}=\mathrm{c}_{\mathrm{i}}\left(\mathrm{P}_{\mathrm{A}}, \mathrm{P}_{\mathrm{N}}, \overline{\mathrm{e}} \mathrm{P}^{*}{ }_{\mathrm{A}}, \overline{\mathrm{e}} \mathrm{P}^{*}{ }_{\mathrm{N}} ; \mathrm{X}\right)
$$

Permintaan optimal untuk barang impor

$$
\mathrm{C}_{\mathrm{i}}^{*}=\mathrm{c}_{\mathrm{i}}\left(\mathrm{P}_{\mathrm{A}}, \mathrm{P}_{\mathrm{N}}, \overline{\mathrm{e}} \mathrm{P}_{\mathrm{A}}^{*}, \overline{\mathrm{e}}{ }^{*}{ }_{\mathrm{N}} ; \mathrm{X}\right)
$$

Permintaan optimal untuk uang

$$
\mathrm{M}=f_{M}\left(\mathrm{P}_{\mathrm{M}}, \mathrm{P}_{\mathrm{B}}, \mathrm{P}^{*}{ }_{\mathrm{B}} ; \mathrm{W}\right)
$$

Permintaan optimal untuk surat berharga domestik (domestic bonds)

$$
\mathrm{B}=f_{\mathrm{B}}\left(\mathrm{P}_{\mathrm{M}}, \mathrm{P}_{\mathrm{B}}, \mathrm{P}_{\mathrm{B}}^{*} ; \mathrm{W}\right)
$$

Permintaan optimal untuk surat berharga luar negeri (foreign bonds)

$$
\mathrm{B}^{*}=f^{*}{ }_{B}\left(\mathrm{P}_{\mathrm{M}}, \mathrm{P}_{\mathrm{B}}, \mathrm{P}_{\mathrm{B}}^{*} ; \mathrm{W}\right)
$$

dimana:

$$
\begin{aligned}
& \mathrm{X}=\text { belanja total (expenditure total) } \\
& \mathrm{W}=\operatorname{kekayaan} \text { nominal (nimonal wealth) }
\end{aligned}
$$

\section{II.4. Permintaan Ekspor}

Proses derivasi rinci dari permintaan ekspor dapat dilihat dalam lampiran IV.4. Adapun hasil derivasi permintaan ekspor Indonesia dapat dirumuskan sebagai berikut:

Permintaan ekspor pertanian

$$
\mathrm{C}_{\mathrm{A}}=\mathrm{c}_{\mathrm{A}}\left(\mathrm{e} \mathrm{P}_{\mathrm{A}}, \mathrm{eP}_{\mathrm{N}}, \mathrm{P}_{\mathrm{A}}^{*}, \mathrm{P}_{\mathrm{N}}^{*} ; \mathrm{X}^{*}\right)
$$

Permintaan eskpor non pertanian

$$
\mathrm{C}_{\mathrm{N}}=\mathrm{c}_{\mathrm{N}}\left(\mathrm{e} \mathrm{P}_{\mathrm{A}}, \mathrm{eP}_{\mathrm{N}}, \mathrm{P}_{\mathrm{A}}^{*}, \mathrm{P}_{\mathrm{N}}^{*} ; \mathrm{X}^{*}\right)
$$

dimana:

$\mathrm{e}=$ kurs unit mata asing pe unit Rupiah atau $\mathrm{e}=1 / \overline{\mathrm{e}}$

$\mathrm{C}_{\mathrm{i}}=$ permintaan ekspor untuk $\mathrm{i}=\mathrm{A}, \mathrm{N}$ (dalam nilai riil)

$\mathrm{P}_{\mathrm{i}}=$ Harga ekspor dalam rupiah

$\mathrm{P}_{\mathrm{i}}^{*}=$ Level harga dunia dalam mata uang asing

$\mathrm{X}^{*}=$ Belanja konsumsi dunia dalam mata uang asing

Dengan demikian permintaan ekspor komoditas Indonesia adalah fungsi dari harga ekspor, harga dunia, kurs dan belanja konsumsi dunia. 


\section{METODE PENELITIAN}

\section{III.1 Prosedur Ekonometrika}

Penelitian ini menggunakan teknik ekonometrika untuk data time series. Banyak metode yang digunakan untuk menganalisis data time series. Untuk data multivariate, setidaknya ada empat pendekatan yaitu Cowles Commision (CC), The London School of Economics (LSE), Vector Autoregresive (VAR) dan GMM-Calibration (lihat Siregar, 2002). Metode VAR merupakan salah satu bentuk model makro-ekonometrika yang sering digunakan untuk melihat permasalahan fluktuasi ekonomi.

Model terakhir yang telah banyak dikembangkan adalah model VAR dan Structural Vector Autoregresive (SVAR). Pendekatan ini mampu mengatasi kritik Lucas yang ditujukan pada analisis kebijakan untuk model-model makro ekonomi dinamik dan stokastik. Model makro ekonomi tradisional menganggap model yang diestimasi pada keadaan tertentu dapat digunakan untuk peramalan pada kondisi rezim kebijakan yang berbeda. Hal ini menunjukkan bahwa parameter yang diestimasi tidak berubah pada kebijakan dimanapun perekonomian berada sehingga model ekonomi secara logik menjadi tidak valid. Sedangkan Struktural VAR tidak hanya menghasilkan rekomendasi berdasarkan keluaran modelnya dalam merespon adanya suatu guncangan dalam perekonomi tetapi membiarkan hal ini bekerja melalui model teoritik ${ }^{3}$ dan dapat melihat respon jangka panjang berdasarkan data historisnya.

Vector Autoregresive (VAR) adalah suatu sistem persamaan yang memperlihatkan setiap variabel sebagai fungsi linier dari konstanta dan nilai lag (lampau) dari variabel itu sendiri serta nilai lag dari variabel lain yang ada dalam sistem. Variabel penjelas dalam VAR meliputi nilai lag seluruh variabel tak bebas dalam sistem VAR membutuhkan identifikasi retriksi yang sangat ketat untuk mencapai persamaan melalui interpretasi persamaan. Restriksi-retriski persamaan dilakukan dalam struktural VAR apabila memang diperlukan dan didasarkan pada teori ekonomi yang relevan.

VAR dengan ordo $p$ dan $n$ buah variabel tak bebas pada peride $t$ dapat dimodelkan sebagai berikut:

$$
Y_{t}=A o+A_{1} Y_{t-1}+A_{2} Y_{t-2} \ldots \ldots+A_{p} Y_{t-p}+\varepsilon_{t}
$$

dimana $\quad \mathrm{Y}_{\mathrm{t}}=$ vektor variabel tak bebas $\left(\mathrm{Y}_{1 . \mathrm{t}^{\prime}}, \mathrm{Y}_{2 . \mathrm{t}^{\prime}} \mathrm{Y}_{\mathrm{n} . \mathrm{t}^{\mathrm{f}}}\right)$ Ao $=$ vektor intersep berukuran $\mathrm{n} \times 1$

3 Bedakan dengan Model VAR yang sering disebut a-theory, model Struktural VAR sebenarnya tidak bisa lagi dikatakan sebagai model yang a-theory karena didalam model tersebut melalui imposing restriction pada koefisien jangka panjang atau matrik_ (menempatkan suatu varabel sebagai variable endogen atau eksogen, dan dimungkinkan juga memberikan angka restriksi pada koefisien-koefisien estimasinya) yang mana pemberian restriksi berlandaskan pada informasi dari teori atau bukti empiris yang kuat. 


$$
\begin{aligned}
& A_{1}=\text { matrik parameter berukuran } n \times 1 \\
& \varepsilon_{t}=\text { vektor sisaan }\left(\varepsilon_{1 . t}, \varepsilon_{2 . t}, \varepsilon_{n . t}\right) \text { berukuran } n \times 1
\end{aligned}
$$

Persamaan VAR secara umum menurut Thomas (1999) adalah sebagai berikut

$$
\mathrm{Y}_{\mathrm{t}}=\sum_{\mathrm{i}=1}^{\mathrm{k}} \mathrm{A}_{\mathrm{i}} \mathrm{Y}_{\mathrm{t}-1}+\mathrm{C}_{\mathrm{t}}
$$

dimana

$Y_{t}=$ Vektor kolom dari observasi pada waktu $t$ semua variabel dalam model

$A_{t}=$ Matrik parameter

$\mathrm{k}=$ Ordo dari model VAR

Asumsi yang harus dipenuhi dalam analisis VAR adalah semua variabel tak bebas bersifat stasioner, semua sisaan bersifat white noise, yaitu memiliki rataan nol, ragam konstan dan diantara variabel tak bebas tidak ada korelasi. Uji kestasioneran data dapat dilakukan melalui pengujian terhadap ada tidaknya unit root dalam variabel dengan uji Augmented Dickey Fuller $(A D F)$, adanya unit root akan menghasilkan persamaan regresi yang spurious.

Pendekatan yang dilakukan untuk mengatasi persamaan regresi yang spurious adalah dengan melakukan diferensiasi atas variabel endogen dan eksogennya, sehingga diperoleh variabel yang stasioner dengan derajat $\mathrm{I}(\mathrm{n})$. Kestasioneran data melalui pendiferensialan belum cukup, kita perlu mempertimbangkan keberadaan hubungan jangka panjang dan jangka pendek dalam model.

Pendeteksian keberadaan kointegrasi ini dilakukan dengan metode Johansen atau EngelGranger. Jika variabel-variabel tidak terkointegrasi, kita dapat menerapkan VAR standar yang hasilnya akan identik dengan OLS, setelah memastikan variabel tersebut sudah stasioner pada derajat (ordo) yang sama. Jika pengujian membuktikan terdapat vektor kointegrasi, maka kita akan menerapkan ECM untuk single equation atau VECM untuk system equation.

Derivasi vector error correction (VECM) didasarkan pada teorema Johansen (1988). Misalkan $\{Z\}$ adalah tingkat derajat VAR ke-p dan $Z_{t}=\{Y: X)$, dimana $Y$ adalah vektor variabel endogen dan $X$ adalah vektor variabel eksogen. Hal ini dapat dinyatakan sebagai berikut:

$$
\mathrm{Z}_{\mathrm{t}}=\sum_{\mathrm{i}=1}^{\mathrm{p}} \prod \mathrm{Z}_{\mathrm{t}-1}+\psi_{\mathrm{y}} \mathrm{W}_{\mathrm{t}}+\mathrm{a}_{\mathrm{o}}+\varepsilon_{\mathrm{t}}
$$

dimana $\quad \varepsilon_{\mathrm{t}}=$ gaussian error term

$\mathrm{w}_{\mathrm{t}}=$ vektor variabel-variabel stationer

Satu vektor time series $Z_{t}$ mempunyai representasi error correction jika ia dapat di ekspresikan sebagai berikut: 


$$
\Delta \mathrm{Z}_{\mathrm{t}}=\sum \Gamma_{\mathrm{i}} \Delta \mathrm{Z}_{\mathrm{t}-\mathrm{i}}+\prod_{\mathrm{i}=1}^{\mathrm{p}-1} \mathrm{Z}_{\mathrm{t}-p}+\psi_{\mathrm{y}} \mathrm{w}_{\mathrm{t}}+\mathrm{a}_{\mathrm{o}}+\varepsilon_{\mathrm{t}}
$$

dimana: $\Gamma_{\mathrm{i}} \quad=-\mathrm{I}+\prod_{1}+\ldots+\prod_{\mathrm{i}} \quad(\mathrm{i}=1,2, \ldots p-1)$

$$
\begin{aligned}
& \Pi \quad=-\left(\mathrm{I}-\prod_{1}-\ldots-\prod_{p}\right)=\quad \alpha \beta^{\prime} \\
& \varepsilon_{\mathrm{t}}=\left[\begin{array}{c}
\varepsilon_{\mathrm{yt}} \\
\varepsilon_{\mathrm{xt}}
\end{array}\right], \quad a_{\mathcal{O}}=\left[\begin{array}{l}
a_{y} \\
a_{x 0}
\end{array}\right], \prod=\left[\begin{array}{l}
\prod_{\mathrm{y}} \\
0
\end{array}\right], \quad \Gamma_{\mathrm{i}}=\left[\begin{array}{c}
\Gamma_{\mathrm{yi}} \\
\Gamma_{\mathrm{xi}}
\end{array}\right]
\end{aligned}
$$

Ada dua cara untuk mengestimasi persamaan regresi (4) yakni: Pertama, Johansen memberikan prosedur unified maximum likelihood yang mana $\alpha$ dan $\beta$ didapat dari dekomposisi matrik $\prod$. Kedua, Engle dan Granger (1987) mengajukan dua langkah estimasi menggunakan regresi kointegrasi sehingga $\beta^{\prime} Z_{t-1}$, residual estimasi (estimated residual) di masukkan pada persamaan regresi di atas. Penelitian ini akan mengadopsi prosedur Johansen.

Satu restriksi yang akan dimasukkan ke dalam model estimasi VEC yakni pada koefisien jangka panjangnya ( $\beta$ ). Model teoritis menunjukkan bahwa $\beta$ bukan matrik full rank. Dikarenakan ukuran sample yang kecil, pemasukkan semua variabel-variabel lag first difference dalam masingmasing persamaan dalam VEC akan mengurangi secara signifikan degree of freedom. Oleh karena itu untuk mengatasi masalah tersebut prosedur yang akan ditempuh adalah seperti yang disarankan oleh Sugema (1992) yakni model akan dibagi menjadi beberapa blok, selanjutnya variabel-variabel yang dimasukkan ke dalam model didasarkan pada model teoritisnya. Berdasarkan pembagian tersebut maka dibentuk lima blok dalam VEC yakni Blok Permintaan Komoditas, Blok Permintaan Aset, Blok/sektor Pertanian, Blok/sektor non Pertanian dan Blok Ekspor Komoditas. Walaupun demikian titik tekan analisa adalah pada blok pertanian saja dimana blok-blok lain dilihat sebagai variabel eksogenus yang mempengaruhi variabelvariabel yang ada dalam blok pertanian melalui disequilibrium error dari masing-masing persamaan pada setiap blok di luar sektor pertanian.

Dengan demikian untuk Blok/Sektor Pertanian terdiri atas tiga vektor kointegrasi yang diidentifikasi sebagai persamaan-persamaan sebagai berikut: Penawaran (output) Pertanian, Permintaan Tenaga Kerja sektor pertanian dan Permintaan Modal Sektor Pertanian.

Tidak seperti prosedur lainnya, metode Johansen mengintegrasikan persamaan dinamik jangka panjang dan jangka pendek dalam satu kesatuan. Lebih dari itu metode ini juga dapat menentukan jumlah vektor kointegrasi (jumlah persamaan keseimbangan jangka panjangnya). Informasi dari Hall dalam Sugema (2000) mengatakan penggunaan metode ini setidaknya akan menghadapi dua masalah praktis yakni: Pertama, uji statistik yang digunakan untuk menentukan 
jumlah persamaan kointegrasi dan estimasi koefisien jangka panjang sangat sensitif dengan penentuan jumlah lag yang dimasukkan ke dalam persamaan VARnya. Kedua, Terjadinya multi kolinearitas. Oleh karena itu penentuan dalam penentuan order lag yang digunakan sebelumnya akan dilakukan terlebih dahulu uji Ordo VAR berdasarkan criteria Schwarz Information Criterion, Hannan-Quinn Information Criterion, Final Prediction Error atau Akaike Information Criterion.

\section{III.2. Spesifikasi Model VECM}

Model yang dipergunakan dalam penelitian ini, mengandung 35 Variabel (lihat Lampiran 1), dengan demikian vektor $Z$ merupakan vektor $35 \times 1$ sebagai berikut:

$\mathrm{Z}_{\mathrm{t}}=$ (LPA, LPN, LPBINA, LPBINN1, LX, LPM, LPB, LPBIN_B, LW, LWA/LPA, LPMA/LPA, r, LWN/LPN, LPMN/LPN, LP_A LP_N, LXBIN, LREER, LC, , LC, LC_BINA, LCBIN_N1, LM2, LB, LBBIN, LYA, LLA, LKA, LYN, LLN, LKN, LC_A, LC_N)

Jika VARnya memiliki ordo $\mathrm{p}$ maka $\mathrm{Z}_{\mathrm{t}}$ menjadi:

$$
Z_{t}=\sum_{i=1}^{p} \prod_{i} Z_{t-1}+\varepsilon_{t}
$$

Persamaan 1 di atas dapat ditulis dalam bentuk first difference sebagai berikut:

$$
\Delta \mathrm{Z}_{\mathrm{t}}=\prod_{\mathrm{i}} \mathrm{Z}_{\mathrm{t}-1}+\sum_{\mathrm{i}=1}^{\mathrm{p}} \Gamma_{\mathrm{i}} \Delta \mathrm{Z}_{\mathrm{t}-\mathrm{i}}+\varepsilon_{\mathrm{t}}
$$

dimana: $\Pi=\alpha \beta$ adalah matrik $34 \times 34$ parameter

$\Delta \mathrm{Z}_{\mathrm{t}} \quad=$ vektor first difference

$\Gamma_{\mathrm{i}} \quad=34 \times 34$ matrik koefisien

$\varepsilon_{\mathrm{t}}=34 \times 1$ vektor proses white noise

$\beta=34 \times 15$ cointegrating vector

$\alpha \quad=34 \times 15$ matrik koefisien

Matriks $\beta$ dapat diestimasi dengan menggunakan regresi kointegrasinya sehingga dapat dihasilkan error correction term $\mathrm{E}_{\mathrm{t}-1}=\beta \mathrm{Z}_{\mathrm{t}-1}$. Dengan demikian $\prod_{\mathrm{i}} \mathrm{Z}_{\mathrm{t}-\mathrm{i}}$ dapat diestimasi sebagai $\alpha E_{t-1}$. Komponen $E_{t-1}$ merupakan $15 \times 1$ vektor disequilibrium error jangka panjang. Adapun analisis Vector Error Correction Model untuk sektor pertanian adalah sebagai berikut:

$$
\Delta \mathrm{Z}_{3, \mathrm{t}}=\alpha \mathrm{E}_{\mathrm{t}-1}+\sum_{\mathrm{i}=1}^{\mathrm{p}} \Gamma_{\mathrm{i}} \Delta \mathrm{Z}_{3, \mathrm{t}-\mathrm{i}}+\varepsilon_{3 \mathrm{t}}
$$


dimana: $\mathrm{Z}_{3}=7 \times 1$ vektor untuk variabel-variabel $\left(\mathrm{lwa} / \mathrm{lp}_{\mathrm{A}}, \mathrm{IP}_{\mathrm{mA}} / \mathrm{PP}_{\mathrm{A}}, \mathrm{r}, 1 \mathrm{P}_{\mathrm{A}}, 1 \mathrm{Y}_{\mathrm{A}}, 1 \mathrm{~L}_{\mathrm{A}}\right.$ dan $\left.1 \mathrm{~K}_{\mathrm{A}}\right)$

$\mathrm{E}_{\mathrm{t}-1}=$ error correction term pada setiap persamaan pada masing-masing blok pada periode sebelumnya

$\alpha_{3}=7 \times 15$ matrik koefisien

\section{III.3. Data}

Data yang digunakan adalah data runtut waktu bulanan 1993:01 sampai 2002:12 diperoleh dari publikasi statistik lembaga-lembaga berikut: Bank Indonesia (BI), Badan Pusat Satistik (BPS), CEIC data Company limited dan dari International Financial Statistics IMF. Sampel observasi data dipilih dari tahun 1993 - 2002 karena mempertimbangkan pada jangka waktu tersebut ekonomi Indonesia telah terintegrasi secara signifikan dengan perekonomian internasional yang ditandai oleh dengan lahirnya kebijakan-kebijakan yang bersifat outward looking seperti deregulasi perekonomian dan liberalisasi sektor pertanian. Sedangkan data bulanan yang dipilih karena pertimbangan teknis statistik untuk mengatasi masalah degree of freedom mengingat jika digunakan series tahunan atau triwulanan akan mengalami masalah degree of freedom.Adapun rincian variabel, data yang digunakan, teknik perhitungannya dan sumber data dapat dilihat pada Lampiran IV.1.

\section{ANALISIS KESEIMBANGAN JANGKA PANJANG}

Sesuai dengan teknik analisis data runtun waktu (time series), ke 35 variabel yang dipergunakan terlebih dahulu diuji kestasionerannya dengan mempergunakan uji Augmented Dickey Fuller (ADF). Pengujian ini berdasarkan pada nilai Schwarz Information Criterion yang terbesar (Pesaran and Pesaran dalam Siregar, 2002). Semakin besar Schwarz Information Criterion akan didapat model yang semakin siknifikan. Model dengan Schwarz Information Criterion terbesar berarti model tersebut mempunyai lag yang optimum. Langkah selanjutnya adalah membandingkan antara nilai t-statistic dengan nilai kritis (critical value) 95 dan 99 persen. Jika nilai t-statistitik lebih besar dari critical value maka data stasioner I(0) berarti dapat dilakukan analisis hanya dengan pendekatan VAR saja tetapi apabila lebih kecil dari critical value maka data non stasioner. Hasil pengujian unit root menunjukkan semua variabel yang digunakan dalam model penelitian menunjukkan stasioner pada I(1).

Hasil uji ordo VAR untuk variabel-variabel yang digunakan berdasarkan kriteria Schwarz information criterion dan Hannan-Quinn information criterion menunjukkan lag yang optimal adalah persamaan VAR dengan ordo 1 (lihat Tabel IV.1). Sedangkan Hasil Uji kointegrasi Johansen 
menunjukkan ada 3 vektor kointegrasi pada taraf kepercayaan $5 \%$ (lihat Tabel IV. 2). Hasil restriksi yang over identifiying, ditandai dengan nilai p-value sebesar 0.000000 , menunjukkan bahwa hipotesis null ditolak pada taraf siknifikansi $\alpha=1 \%$. Penolakan $\mathrm{HO}$ ini merupakan kecenderungan umum pada penerapan over identifying restriction dalam suatu sistem kointegrasi dengan $n$ yang terbatas (Siregar, 2002). Oleh karena itu pada kondisi $n$ yang terbatas tersebut walaupun terjadi tolak Ho diasumsikan over identifying restriction tersebut masih dapat digunakan.

\begin{tabular}{|c|c|c|c|c|c|c|}
\hline Lag & $\log L$ & LR & FPE & AIC & SC & $\mathrm{HQ}$ \\
\hline 0 & 738,1074 & NA & $1,70 \mathrm{E}-14$ & $-11,84399$ & $-10,33188$ & $-11,23031$ \\
\hline 1 & 1985,777 & 2145,116 & $1,26 E-23$ & $-32,87328$ & $-30,18508^{*}$ & $-31,782 *$ \\
\hline 2 & 2047,322 & 98,25729 & $1,04 \mathrm{E}-23$ & $-33,09338$ & $-29,22910$ & $-31,52508$ \\
\hline 3 & 2089,168 & 61,66643 & $1,24 \mathrm{E}-23$ & $-32,96785$ & $-27,92749$ & $-30,92225$ \\
\hline 4 & 2142,331 & 71,81696 & $1,25 E-23$ & $-33,04089$ & $-26,82444$ & $-30,51798$ \\
\hline 5 & 2208,005 & 80,65202 & $1,06 E-23$ & $-33,33341$ & $-25,94088$ & $-30,33320$ \\
\hline 6 & 2283,506 & 83,44876 * & 7,97E-24* & $-33,79835 *$ & $-25,22973$ & $-30,32082$ \\
\hline Keterangan: & \multicolumn{6}{|c|}{$\begin{array}{l}\text { * Mengindikasi jumlah lag yang optimum untuk VAR berdasarkan kriteria pemilihan: } \\
\text {-LR: sequential modified LR test statistic (each test at } 5 \% \text { level) } \\
\text {-FPE: Final prediction error HQ: Hannan-Quinn information criterion } \\
\text { - AIC: Akaike information criterion SC: Schwarz information criterion } \\
\text {-Jumlah Observasi yang digunakan: } 114\end{array}$} \\
\hline
\end{tabular}

Tabel IV.2. Uji Kointegrasi Johansen Blok Produksi Pertanian

\begin{tabular}{|c|c|c|c|c|}
\hline \multirow{2}{*}{$\begin{array}{l}\text { JUMLAH } \\
\text { PERSAMAAN } \\
\text { KOINTEGRASI YANG } \\
\text { DIHIPOTESISKAN }\end{array}$} & & Max-Eigen & 5 Percent & 1 Percent \\
\hline & Eigenvalue & Statistic & Critical Value & Critical Value \\
\hline None $* *$ & 0,458124 & 71,07538 & 41,51 & 47,15 \\
\hline At most $1 * *$ & 0,324629 & 45,52925 & 36,36 & 41,00 \\
\hline At most 2 * & 0,240220 & 31,86820 & 30,04 & 35,17 \\
\hline At most 3 & 0,174947 & 22,30773 & 23,80 & 28,82 \\
\hline At most 4 & 0,129201 & 16,04785 & 17,89 & 22,99 \\
\hline At most 5 & 0,054403 & 6,488928 & 11,44 & 15,69 \\
\hline At most 6 & 0,030842 & 3,633998 & 3,84 & 6,51 \\
\hline \multicolumn{5}{|c|}{$\begin{aligned} \text { Keterangan : } & { }^{*}(* *) \text { menunjukan penolakan hipotesis pada taraf kepercayaan } 5 \% \text { (1 persen) } \\
& \text { - Max-eigenvalue test indikasikan ada } 3 \text { persamaan kointegrasi pada taraf 5\% } \\
& \text { - Max-eigenvalue test indikasikan ada } 2 \text { persamaan kointegrasi pada taraf 1\% } \\
& \text { - Sample (adjusted): 1993:05 2002:12 } \\
& \text { - Jumlah observasi yang digunakan: } 116 \text { after adjusting endpoints } \\
& \text { - Asumsi Trend: Tidak ada deterministic trend } \\
& \text { - Lags interval ( dalam first differences): } 1 \text { to } 1\end{aligned}$} \\
\hline
\end{tabular}


Hasil restriksi yang bermakna secara ekonomi dapat dilihat pada Tabel IV.3, dimana terdapat 3 persamaan jangka panjang ter-restriksi yang diidentifikasi sebagai persamaan output pertanian $\left(\mathrm{Y}_{A}\right)$, persamaan permintaan input tenaga kerja $\left(\mathrm{L}_{A}\right)$ dan persamaan permintaan input modal $\left(\mathrm{K}_{\mathrm{A}}\right)$.

Tabel IV.3. Vektor Kointegrasi Over Identified untuk Blok Produksi Pertanian

\begin{tabular}{|c|c|c|c|c|c|c|}
\hline LYA & LKA & LLA & $r$ & LWAVLPA & LPMALPA & LPA \\
\hline 1 & 0 & 0 & 0,003000 & 0,409000 & 0,007000 & $-1,335607$ \\
\hline (0) & (0) & (0) & $(0,00000)$ & $(0,00000)$ & $(0,00000)$ & $(0,06073)$ \\
\hline 0 & 1 & 0 & 0,001190 & $-1,965968$ & 1,666536 & $-1,073956$ \\
\hline (0) & (0) & (0) & $(0,00000)$ & $(0,11803)$ & $(0,36388)$ & $(0,05775)$ \\
\hline 0 & 0 & 1 & $-0,000300$ & 0,045674 & $-3,276965$ & $-0,770292$ \\
\hline (0) & (0) & (0) & $(0,00000)$ & $(0,00000)$ & $(0,81994)$ & $(0,12070)$ \\
\hline Keteranga & $\begin{array}{l}\text { latis } \\
\text { ka di }\end{array}$ & $\begin{array}{l}\text { 48.482 } \\
\text { dalam }\end{array}$ & $\begin{array}{l}\text { P-value }=0.000 \\
\text { g kecuali suku } \\
\text { kan standard er }\end{array}$ & & & \\
\hline
\end{tabular}

Adapun nilai koefisien elastisitas harga jangka panjang dari tiga persamaan kointegrasi yang dihasilkan dapat dilihat pada Tabel IV.4. Elastisitas harga yang diestimasi telah sesuai dengan yang diharapkan. Nilai elastisitas output pertanian terhadap harga output, sebesar 1.33, berarti bahwa jika terjadi kenaikan harga 1\% maka akan meningkatkan produksi pertanian sebesar $1.33 \%$ dalam jangka panjang.

Elastisitas output terhadap harga-harga input menunjukkan nilai negatif dan inelastis (kurang dari 1) yang berarti kenaikan harga-harga input (upah tenaga kerja, harga input material dan harga modal) akan menurunkan output pertanian tetapi dengan proporsi yang lebih rendah dari kenaikan harga-harga input tersebut.

Dari persamaan jangka panjang pemintaan input memperlihatkan hubungan antara input tenaga kerja dan modal yang bersifat subtitusi yang ditunjukkan dari nilai elastisitas permintaan tenaga kerja terhadap harga input modal yang positif, walaupun demikian besaran koefisien yang kurang dari 1 (inelastis) yakni 0.0003 menunjukkan kenaikan harga input modal hampir tidak memberikan kenaikan yang berarti dalam penggunaan tenaga kerja dimana kenaikan $1 \%$ harga input modal hanya akan meningkatkan penggunaan tenaga kerja sebesar $0.0003 \%$.

Angka elastisitas permintaan tenaga kerja terhadap harga input material yang positif menunjukkan hubungan antara input tenaga kerja dan input material adalah bersifat 


\begin{tabular}{|c|c|c|c|c|}
\hline \multirow[b]{2}{*}{ PERSAMAAN } & \multicolumn{4}{|c|}{ ELASTISITAS } \\
\hline & $\begin{array}{l}\text { Tingkat Upah } \\
\text { tenaga kerja } \\
\text { pertanian riil } \\
\left(\text { Lwa/LP } P_{A}\right)\end{array}$ & $\begin{array}{l}\text { Harga Input } \\
\text { Material Riil } \\
\left(\mathrm{LP}_{\mathrm{mA}} / \mathrm{LP}_{\mathrm{A}}\right)\end{array}$ & $\begin{array}{l}\text { Harga modal } \\
\text { (real interest } \\
\text { rate)(r) }\end{array}$ & $\begin{array}{l}\text { Harga Output } \\
\left(\mathrm{LP}_{\mathrm{A}}\right)\end{array}$ \\
\hline $\begin{array}{l}\text { output } \\
\text { Pertanian }\left(L Y_{A}\right)\end{array}$ & $-0,409$ a & $-0,007^{b}$ & $-0,003^{c}$ & $\begin{array}{l}1,33 \\
(0,06073)\end{array}$ \\
\hline $\begin{array}{l}\text { Permintaan } \\
\text { Tenaga kerja } \\
\text { Pertanian }\left(\mathrm{LL}_{\mathrm{A}}\right)\end{array}$ & $-0,045^{d}$ & $\begin{array}{l}3,27 \\
(0,81994)\end{array}$ & $0,0003^{e}$ & $\begin{array}{l}0,77 \\
(0,1207)\end{array}$ \\
\hline $\begin{array}{l}\text { Permintaan } \\
\text { Modal untuk } \\
\text { Pertanian }\left(\mathrm{LK}_{\mathrm{A}}\right)\end{array}$ & $\begin{array}{r}1,97 \\
(0,11803)\end{array}$ & $\begin{array}{l}-1,66 \\
(0,36388)\end{array}$ & $-0,001^{f}$ & $\begin{array}{l}1,07 \\
(0,05775)\end{array}$ \\
\hline \multicolumn{5}{|c|}{ 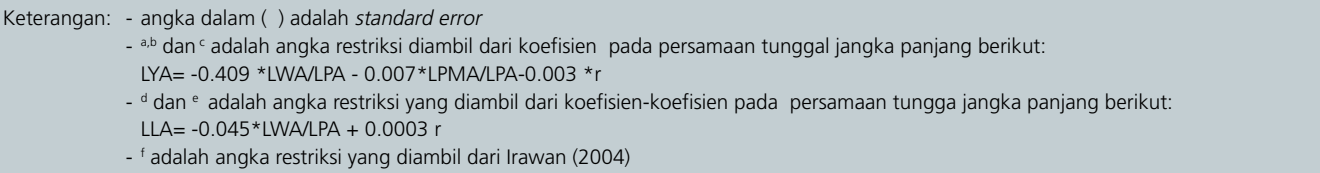 } \\
\hline
\end{tabular}

subtitusi, angka elastisitas sebesar 3.27 menunjukkan jika terjadi kenaikan harga input material sebesar $1 \%$ maka akan meningkatkan penggunaan tenaga kerja sebesar 3.27 persen. Adapun elastisitas permintaan tenaga kerja terhadap harga output adalah inelastis (0.77) dimana kenaikan harga output sebesar $10 \%$ akan meningkatkan permintaan tenaga kerja sektor pertanian sebesar 7.7 persen. Sedangkan elastisitas permintaan tenaga kerja terhadap upah tenaga kerja adalah -0.045 yang berarti jika terjadi kenaikan upah tenaga kerja sebesar $10 \%$ akan mengurangi permintaan tenaga kerja sebesar 0.45 persen, angka elastisitas yang sangat inelastis ini menunjukkan bahwa tenaga kerja merupakan input yang penting bagi pertanian dimana naik atau turunnya harga yang tinggi tidak mengurangi atau menambah penggunaan tenaga kerja secara berarti.

Elastisitas permintaan modal terhadap harga modal adalah inelastis dan negatif (-0.001) dimana naik-turunnya harga modal tidak merubah permintaan sektor pertanian terhadap modal secara berarti. Angka elastisitas permintaan modal terhadap tingkat upah tenaga kerja yang positif dan elastis menunjukkan tenaga kerja merupakan input yang mampu menggantikan modal (bersifat subtitusi) dimana jika terjadi kenaikan upah tenaga kerja sebesar $1 \%$ maka akan meningkatkan penggunaan input modal sebesar 1.97 persen. Sedangkan elastisitas permintaan modal terhadap harga output adalah positif dan elastis (1.07), yang menunjukkan jika terjadi kenaikan harga output sebesar $1 \%$ maka akan terjadi peningkatan permintaan input modal sebesar 1.07 persen. 


\section{ANALISIS ERROR CORRECTION MODEL}

\subsection{Sumber-sumber Instabilitas Utama sektor Pertanian}

Tujuan utama dari analisis error correction model pada bagian ini adalah untuk mengidentifikasi sumber dari instabilitas penawaran (produksi) dan pemintaan input dalam blok/sektor pertanian. Adapun persamaan error correction mode/nya adalah sebagai berikut:

$$
\Delta \mathrm{Z}_{3, \mathrm{t}}=\alpha \mathrm{E}_{\mathrm{t}-1}+\sum_{\mathrm{i}=1}^{\mathrm{p}-1} \Gamma_{\mathrm{i}} \Delta \mathrm{Z}_{3, \mathrm{t}-\mathrm{i}}+\varepsilon_{3 \mathrm{t}}
$$

dimana: $\mathrm{Z}_{3}=7 \times 1$ vektor untuk variabel-variabel $\left(1 \mathrm{wa} / \mathrm{lp}_{\mathrm{A}}, 1 \mathrm{P}_{\mathrm{mA}} / \mathrm{IP}_{\mathrm{A}}, \mathrm{r}, 1 \mathrm{P}_{\mathrm{A}}, 1 \mathrm{Y}_{\mathrm{A}}, 1 \mathrm{~L}_{\mathrm{A}}\right.$ dan $\left.1 \mathrm{~K}_{\mathrm{A}}\right)$

$\mathrm{E}_{\mathrm{t}-1}=$ error correction term pada setiap persamaan pada masing-masing blok pada periode sebelumnya

$\alpha_{3}=7 \times 15$ matrik koefisien

Tabel IV.5 menyajikan ringkasan koefisien dari disequilibrium error dari setiap persamaan dalam masing-masing blok ekonomi terhadap blok/sektor pertanian. Beberapa temuan empiris yang dapat dilihat dari Tabel IV.5 adalah sebagai berikut:

Pertama, koefisien-koefisien disequilibrium error sumber guncangan bagi output pertanian telah sesuai dengan yang diharapkan dimana: (1) tanda negatif pada koefisien disequilibrium error output menunjukkan jika terjadi lonjakan penawaran di atas keseimbangan jangka panjangnya akan menjadi sumber guncangan yang menurunkan produksi pertanian, (2) tanda positif pada koefisien disequilibrium error permintaan modal menunjukkan jika terjadi kelebihan permintaan modal di atas keseimbangan jangka panjangnya akan menjadi sumber guncangan yang meningkatkan output (produksi) pertanian, dan (3) tanda negatif pada koefisien disequilibrium error permintaan tenaga kerja menunjukkan jika terjadi lonjakan permintaan tenaga kerja di atas keseimbangan jangka panjangnya akan menjadi sumber guncangan yang menaikkan output (produksi) pertanian. Tiga temuan ini menunjukkan bahwa pertumbuhan output pertanian sangat rentan terhadap adanya shock produksi, permintaan modal dan permintaan tenaga kerja pertanian.

Kedua, koefisien-koefisien disequilibrium error sumber guncangan bagi upah riil sektor pertanian juga telah sesuai dengan yang diharapkan dimana: (1) tanda positif pada koefisien disequilibrium error output menunjukkan jika terjadi shock penawaran di atas keseimbangan jangka panjangnya misalnya pada saat panen raya maka akan menjadi sumber guncangan yang meningkatkan upah rill tenaga kerja pertanian karena pada saat itu terjadi peningkatan permintaan tenaga kerja sehingga menjadi sumber shock peningkatan upah tenaga kerja pertanian, (2) tanda negatif pada koefisien disequilibrium error permintaan 
tenaga kerja menunjukkan jika terjadi lonjakan permintaan tenaga kerja di atas keseimbangan jangka panjangnya akan menjadi sumber guncangan yang menurunkan tingkat upah riil tenaga kerja pertanian, (3) tanda negatif pada koefisien disequilibrium error permintaan modal menunjukkan jika terjadi lonjakan permintaan modal di atas keseimbangan jangka panjangnya akan menjadi sumber guncangan yang menurunkan upah riil tenaga kerja pertanian. Hal ini mengindikasikan hubungan modal dan tenaga kerja yang saling subtitusi dimana kelebihan permintaan modal cenderung menurunkan permintaan tenaga kerja. Turunnya permintaan tenaga kerja mengakibatkan turun pula tingkat upah tenaga kerja sektor pertanian.

Ketiga, koefisien-koefisien disequilibrium error sumber guncangan bagi harga output pertanian telah sesuai dengan yang diharapkan dimana: (1) tanda negatif pada koefisien disequilibrium error output menunjukkan jika terjadi lonjakan penawaran di atas keseimbangan jangka panjangnya akan menjadi sumber guncangan yang menurunkan harga output pertanian, (2) tanda positif pada koefisien disequilibrium error permintaan modal menunjukkan jika terjadi lonjakan permintaan modal di atas keseimbangan jangka panjangnya akan menjadi sumber guncangan yang meningkatkan harga output pertanian. Hal ini karena kelebihan permintaan modal berimplikasi pada naiknya harga barang modal yang selanjutnya akan meningkatkan biaya produksi. Peningkatan biaya produksi inilah yang selanjutnya menjadi penyebab naiknya harga output, dan (3) tanda positif pada koefisien disequilibrium error permintaan tenaga kerja menunjukkan jika terjadi lonjakan permintaan tenaga kerja di atas keseimbangan jangka panjangnya akan menjadi sumber guncangan yang menaikkan harga output pertanian. Hal ini karena lonjakan permintaan tenaga kerja tersebut menyebabkan terjadinya naiknya harga tenaga kerja yang berimplikasi pada naiknya biaya input tenaga kerja. Kenaikan input tenaga kerja ini menyebabkan naiknya harga output pertanian.

Keempat, Tanda koefisien disequilibrium error permintaan modal non pertanian yang mempengaruhi output pertanian adalah negatif dan signifikan yang berarti jika terjadi lonjakan permintaan modal non pertanian di atas keseimbangan jangka panjangnya akan menjadi sumber shock yang menurunkan produksi (output) pertanian. Hal ini mengindikasikan lonjakan permintaan modal non pertanian tersebut selanjutnya menjadi sumber shock yang bisa menurunkan produksi.

Kelima, tanda koefisien-koefisien disequilibrium error permintaan aset finansial (permintaan $\mathrm{M} 2$, permintaan bond dalam negeri dan permintaan bond luar negeri) yang mempengaruhi produksi pertanian semuanya bertanda negatif dan signifikan secara statistik. Hal ini menunjukkan terjadinya lonjakan permintaan ketiga aset finansial tersebut di atas 
keseimbangan jangka panjangnya akan memacu kenaikan harga-harga umum termasuk harga komoditas pertanian, dimana kenaikan harga komoditas pertanian ini akan memacu produsen pertanian untuk meningkatkan produksi mereka.

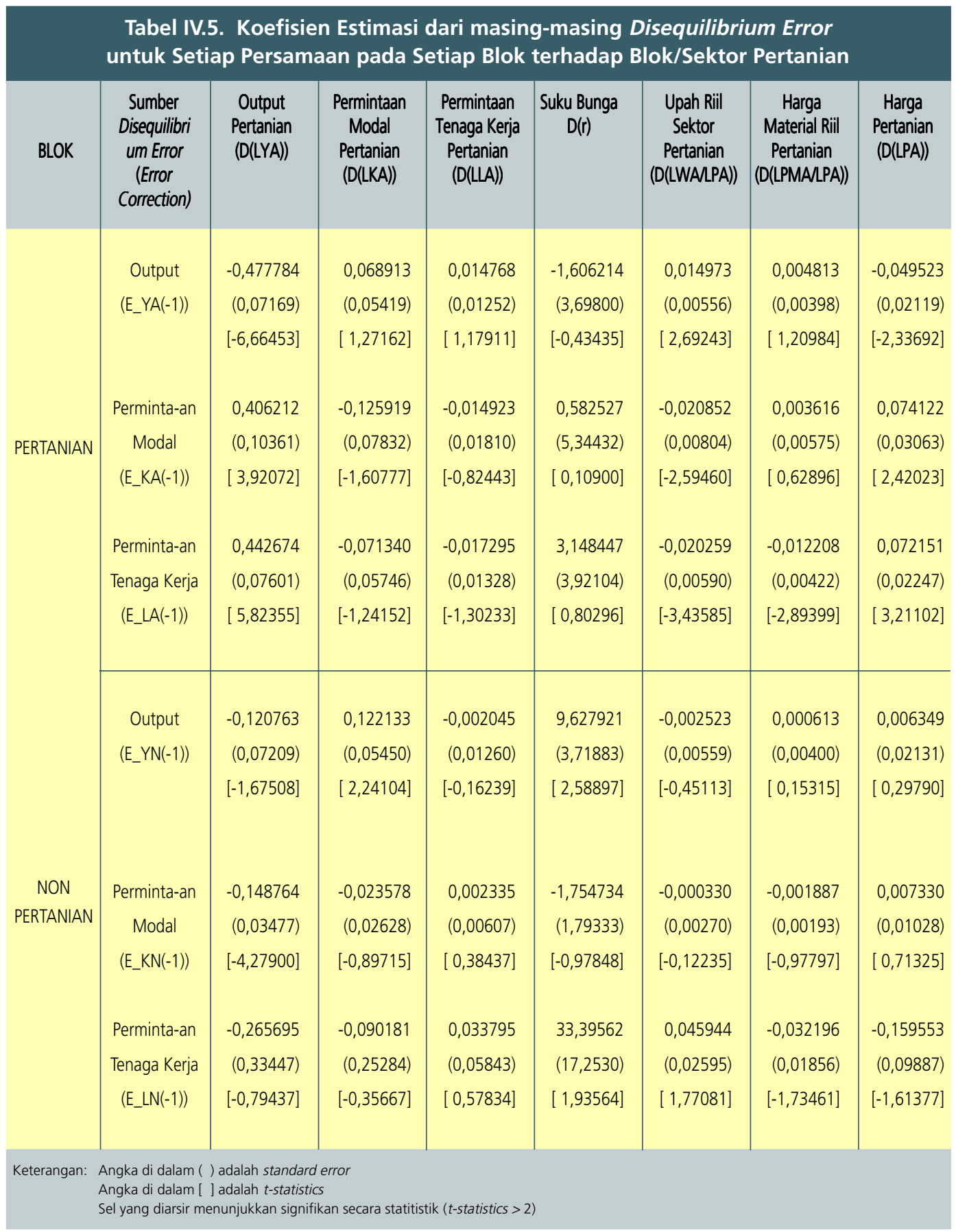




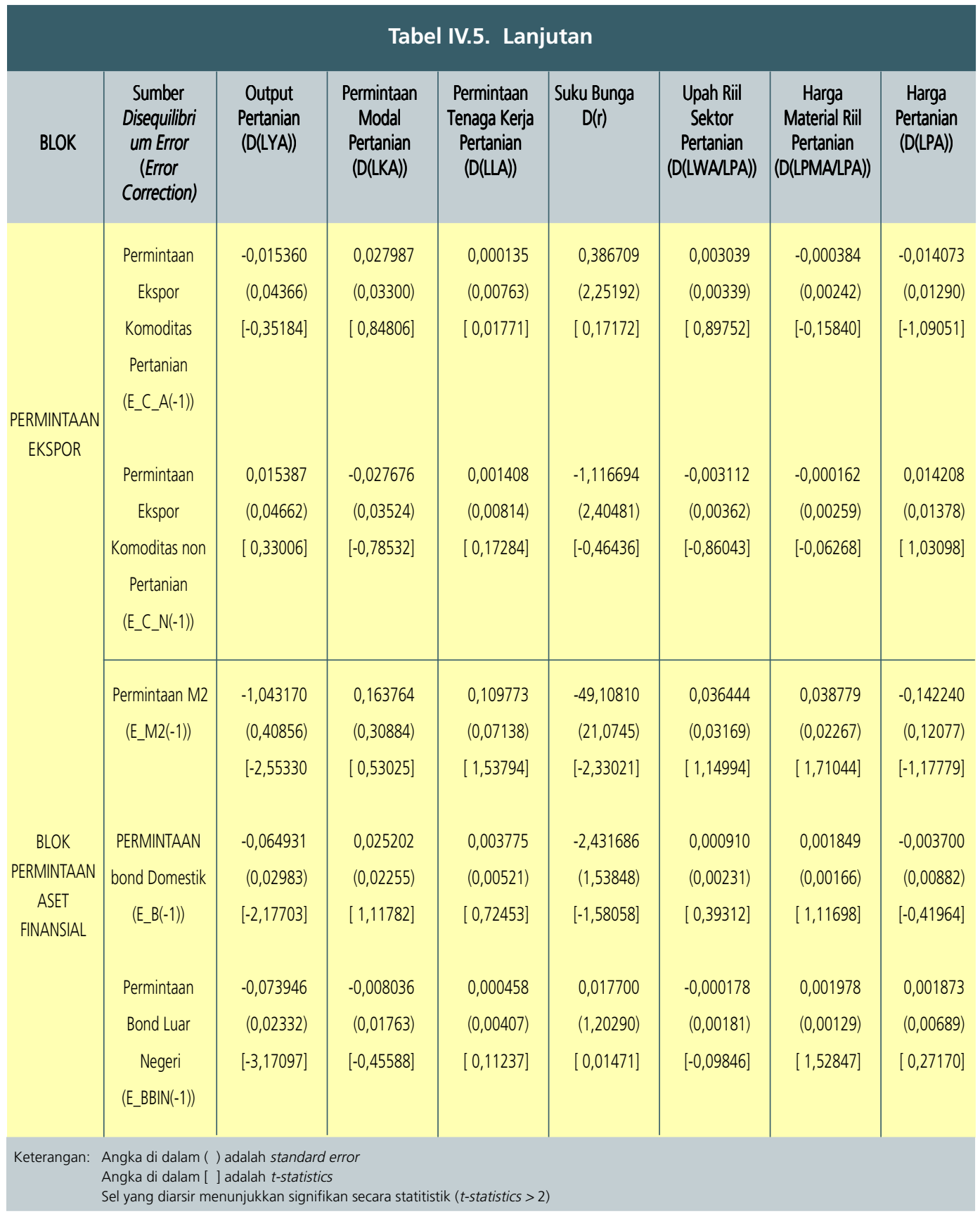




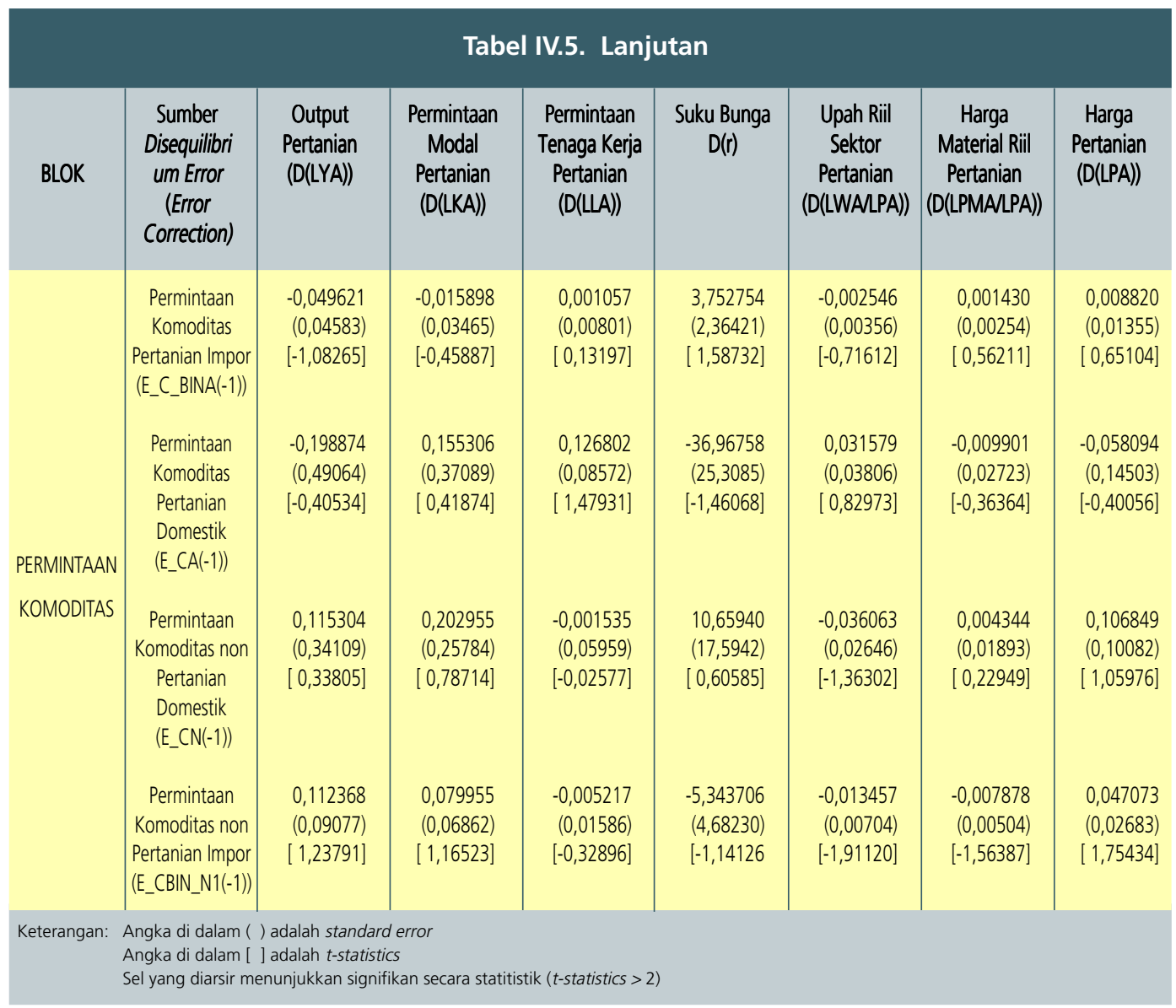

Keenam, jumlah disequlibrium error yang signifikan mempengaruhi harga (input dan output pertanian) ternyata lebih besar dibandingkan dengan jumlah disequilibrium error yang mempengaruhi kuantitas (produksi output dan permintaan input). Hal ini mengindikasikan instabilitas dalam blok/sektor pertanian ini lebih terkait oleh guncangan/ perubahan pada hargaharga (input ataupun output) dibanding karena guncangan/ perubahan kuantitas (output ataupun input).

\section{V.2. Perilaku Harga Output dan Harga Input}

Sub bab ini akan memfokuskan pada kajian sumber inflasi dari sudut pandang supplyside Theory. Berdasarkan sudut pandang Supply-side Theory, inflasi bisa disebabkan oleh kenaikan biaya produksi atau fluktuasi di dalam produksi (output). Penyebab pertama sering juga dikatakan sebagai cost push inflation dalam literatur ekonomi makro. Kemungkinan untuk terjadinya inflasi oleh karena kenaikan biaya produksi (cost push inflation) sangat kuat. 
Indikasi tersebut dapat dilihat dari kecenderungan naiknya harga-harga input penting seperti listrik dan Harga bahan bakar minyak (BBM) yang digunakan untuk produksi (minyak diesel dan premium).

Gambar IV.1 menunjukkan kecenderungan harga listrik rata per KWH yang semakin naik. Kenaikan yang sukup signifikan tampak pada era krisis (1997-2001). Fenomena yang sama juga terjadi untuk harga bahan bakar minyak (BBM) (Gambar IV.2). Kenaikan harga selama periode krisis (1997-2002) hampir empat kali lipat harga premium dan minyak diesel (solar) sebelum krisis (1994- 1996).

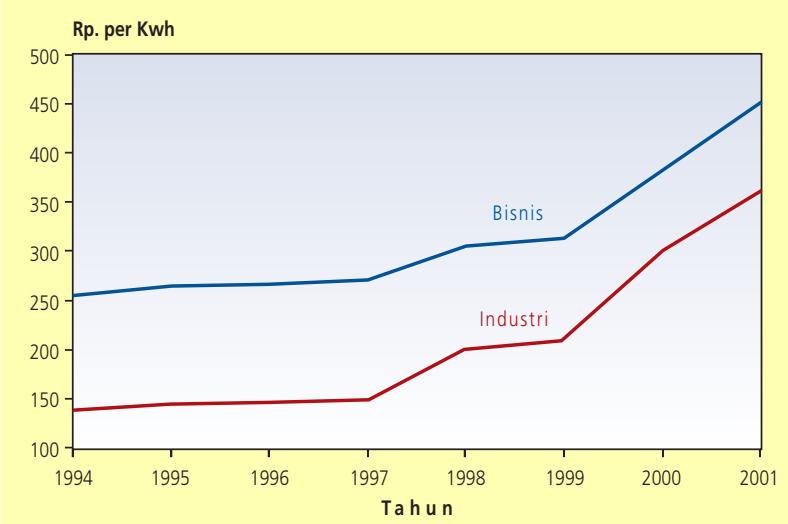

Gambar IV.1. Harga Rata-rata per Kwh Listrik untuk Industri dan Bisnis

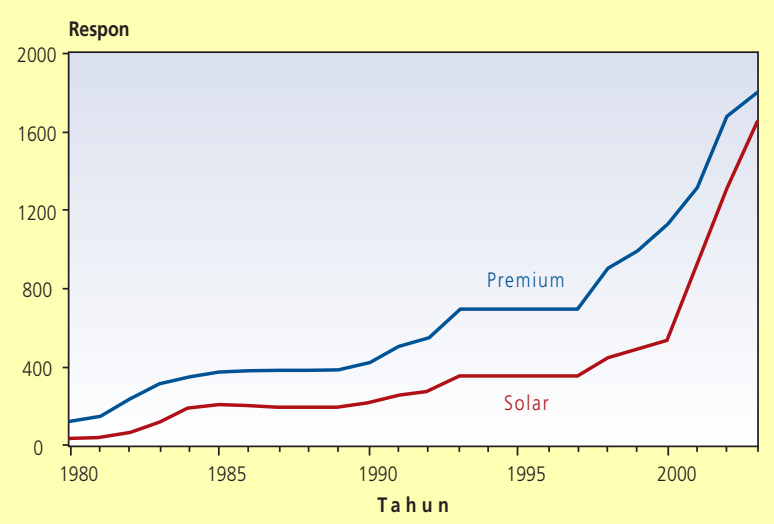

Gambar IV.2. Harga Premium dan Minyak Diesel Sepanjang Periode 1980-2003 


\section{V.2.1. Harga Output Pertanian}

Cost push inflation pada sektor pertanian, terkait erat dengan karakteristik fisik dari produksi pertanian yang sangat tergantung pada kondisi iklim.

\begin{tabular}{|c|c|c|c|c|}
\hline \multicolumn{5}{|c|}{ Blok Pertanian } \\
\hline \multicolumn{2}{|c|}{ Kausalitas } & \multirow[b]{2}{*}{ F-Statistic } & \multirow[b]{2}{*}{ Probability } & \multirow{2}{*}{$\begin{array}{l}\text { Keberadaan } \\
\text { Kausalitas }\end{array}$} \\
\hline Dari & $\mathrm{Ke}$ & & & \\
\hline Suku Bunga & Harga Pertanian & 1,32423 & 0,25222 & Tidak ada \\
\hline $\begin{array}{l}\text { Upah Tenaga Kerja Riil } \\
\text { Pertanian }\end{array}$ & Harga Pertanian & 0,82531 & 0,36553 & Tidak ada \\
\hline $\begin{array}{l}\text { Harga Material Riil } \\
\text { Pertanian }\end{array}$ & Harga Pertanian & 3,56603 & 0,06149 & $A d a^{c}$ \\
\hline Produksi Pertanian & Harga Pertanian & 0,06897 & 0,79331 & Tidak ada \\
\hline
\end{tabular}

Hasil uji Kausalitas Granger (Tabel IV.6) menunjukkan bahwa fenomena cost push inflation relatif tampak dalam inflasi harga komoditas pertanian. Hal ini ditunjukkan dari hasil uji Kausalitas Granger yang menunjukkan adanya kausalitas antara harga material riil pertanian terhadap harga output.

\section{V.2.2. Pergerakan Harga Input}

Sub bab ini akan mendiskusikan kemungkinan adanya umpan balik (feed back) dari harga output dan output itu sendiri terhadap pergerakan harga input. Disamping itu Subbab ini juga akan menganalisis inter-relationship antara harga input untuk medeteksi variabel harga input mana yang menjadi penentu pergerakan harga input lainnya. Analisis ini penting untuk menentukan harga input yang mana yang harus dikontrol pemerintah untuk menstabilisasi sektor pertanian.

Beberapa temuan penting yang terangkum dalam Tabel IV.7 adalah sebagai berikut: Pertama, Tampak adanya kausalitas antara harga output dengan harga bahan material, tetapi tidak ada kausalitas antara harga output dengan dua harga input lainnya (upah tenaga kerja dan suku bunga). Hal ini menunjukkan jika terjadi kenaikan harga output akan menyebabkan para produsen material pertanian akan menaikkan harga material, tetapi kenaikan harga 
output ini tidak menyebabkan pensuplai modal dan tenaga kerja meminta kenaikan harga modal dan harga input tenaga kerja (upah tenaga kerja).

Kedua, tidak ada kausalitas antara kuantitas output (produksi) terhadap harga-harga input pertanian (suku bunga, upah tenaga kerja, harga bahan material). Hal ini menunjukkan kenaikan output (produksi) tidak menstimulasi tenaga kerja untuk meminta kenaikan upah, juga tidak menstimulasi produsen bahan material untuk meminta kenaikan harga material, dan juga tidak menstimulir penyuplai modal untuk meminta kenaikan harga barang modal (yang direpresentasikan oleh suku bunga).

Ketiga, tampak adanya hubungan kausalitas dua arah antara harga material terhadap upah tenaga kerja riil pada taraf $10 \%$ dan sebaliknya kausalitas tenaga kerja riil terhadap harga material pada taraf 1 persen. Fenomena saling mempengaruhi antara kedua harga input ini dapat dijelaskan sebagai berikut: (1) kedua input tersebut bersifat subtitusi satu dengan yang lainnya. Kenaikan tingkat upah yang menyebabkan penurunan penggunaan tenaga kerja akan menyebabkan peningkatan permintaan material (pupuk dan lain-lain) yang selanjutnya meningkatkan harga material yang kemudian akan menurunkan permintaan material dan meningkatkan permintaan tenaga kerja. Kenaikan permintaan tenaga kerja ini menyebabkan kenaikan upah tenaga kerja, dan (2) kedua input tersebut kemungkinan satu dengan lainnya sangat terintegrasi dalam arti deviasi atau disequilibrium di dalam satu pasar input (misalnya pasar bahan material pertanian) akan sangat mudah ditransmisi ke pasar tenaga kerja pertanian (Tabel IV.7).

Keempat, fakta yang menunjukkan bahwa harga output hanya mempengaruhi harga material, dan harga material mempunyai kausalitas dua arah dengan upah tenaga kerja mengindikasikan bahwa jika pemerintah ingin menstabilkan sektor pertanian ini cukup memfokuskan diri pada pasar output saja. Hal itu berarti intervensi untuk menstabilkan sektor pertanian ini tidak memerlukan kebijakan yang integratif di semua pasar input dan pasar outputnya sehingga kebijakan menstabilkan sektor pertanian Indonesia tidak tergolong sebagai kebijakan yang rumit dan sangat mahal. 


\begin{tabular}{|c|c|c|c|c|}
\hline \multicolumn{2}{|c|}{ Kausalitas } & \multirow[b]{2}{*}{ F-Stat. } & \multirow[b]{2}{*}{ Probability } & \multirow{2}{*}{$\begin{array}{c}\text { Keberadaan } \\
\text { Kausalitas }\end{array}$} \\
\hline Dari & $\mathrm{Ke}$ & & & \\
\hline $\begin{array}{l}\text { Harga Komoditas } \\
\text { Pertanian }\end{array}$ & Suku Bunga & 0,54263 & 0,46284 & Tidak ada \\
\hline $\begin{array}{l}\text { Harga Komoditas } \\
\text { Pertanian }\end{array}$ & $\begin{array}{l}\text { Upah Riil Tenaga } \\
\text { Kerja Pertanian }\end{array}$ & 0,65178 & 0,42114 & Tidak ada \\
\hline $\begin{array}{l}\text { Harga Komoditas } \\
\text { Pertanian }\end{array}$ & $\begin{array}{l}\text { Harga Material } \\
\text { Riil Pertanian }\end{array}$ & 17,3839 & $5,9 \mathrm{E}-05$ & $\mathrm{Ada}^{\mathrm{a}}$ \\
\hline Produksi Pertanian & Suku Bunga & 1,53233 & 0,21828 & Tidak ada \\
\hline Produksi Pertanian & $\begin{array}{l}\text { Upah Riil Tenaga } \\
\text { Kerja Pertanian }\end{array}$ & 0,16935 & 0,68146 & Tidak ada \\
\hline Produksi Pertanian & $\begin{array}{l}\text { Harga Material Riil } \\
\text { Pertanian }\end{array}$ & 0,03672 & 0,84837 & Tidak ada \\
\hline Suku Bunga & $\begin{array}{l}\text { Upah Riil Tenaga } \\
\text { Kerja Pertanian }\end{array}$ & 1,31132 & 0,25453 & Tidak ada \\
\hline Suku Bunga & $\begin{array}{l}\text { Harga Material Riil } \\
\text { Pertanian }\end{array}$ & 0,54398 & 0,46229 & Tidak ada \\
\hline $\begin{array}{l}\text { Harga Material Riil } \\
\text { Pertanian }\end{array}$ & Suku Bunga & 0,27985 & 0,59782 & Tidak ada \\
\hline $\begin{array}{l}\text { Harga Material Riil } \\
\text { Pertanian }\end{array}$ & $\begin{array}{l}\text { Upah Riil Tenaga } \\
\text { Kerja Pertanian }\end{array}$ & 3,21777 & 0,07547 & $A d a^{c}$ \\
\hline $\begin{array}{l}\text { Upah Riil Tenaga } \\
\text { Kerja Pertanian }\end{array}$ & $\begin{array}{l}\text { Harga Material Riil } \\
\text { Pertanian }\end{array}$ & 18,3817 & $3,8 \mathrm{E}-05$ & Ada ${ }^{a}$ \\
\hline $\begin{array}{l}\text { Upah Riil Tenaga } \\
\text { Kerja Pertanian }\end{array}$ & Suku Bunga & 0,72364 & 0,39672 & Tidak ada \\
\hline
\end{tabular}

\section{KESIMPULAN DAN IMPLIKASI KEBIJAKAN}

Paling tidak terdapat 3 kesimpulan dan implikasi kebijakan yang diambil dari penelitian ini, pertama, kesimpulan persepektif jangka panjang berkaitan dengan pertumbuhan ekonomi, penyedian lapangan kerja dan investasi dalam sektor pertanian adalah sebagai berikut: Di dalam sektor pertanian, output dan permintaan modal respon terhadap perubahan harga output, sedangkan permintaan tenaga kerja tidak respon terhadap perubahan harga output. Hal ini menunjukkan kenaikan (inflasi) pada harga pertanian akan efektif meningkatkan output dan investasi baru tetapi tidak akan efektif memacu kenaikan penyediaan lapangan kerja. Hal ini menunjukkan untuk mengatasi masalah pengangguran di sektor pertanian strategi demandpull (seperti melalui kebijakan moneter yang longgar) tidak akan efektif, yang lebih efektif untuk mengatasi masalah penyediaan lapangan kerja di sektor pertanian ini adalah strategi 
cost atau produksi dimana stabilisasi harga material akan sangat mendukung penyediaan lapangan kerja di sektor pertanian karena temuan empiris menunjukkan bahwa permintaan tenaga kerja sangat responsif terhadap harga material pertanian. Dengan demikian kebijakan subsidi harga input seperti subsidi pupuk akan membantu untuk mewujudkan strategi cost ini untuk mendukung penyediaan lapangan kerja di sektor pertanian.

Kedua, kesimpulan dan implikasi kebijakan dalam jangka pendek berkaitan dengan sumber instabilitas bagi sektor pertanian Indonesia adalah sebagai berikut:

1. Blok permintaan aset finansial dan blok produksi non pertanian adalah sumber eksternalitas (spillover) terhadap blok (sektor) pertanian. Walaupun demikian yang paling kuat spillovemya adalah blok permintaan aset finasial. Hal ini mengindikasikan blok (sektor) pertanian relatif lebih volatile terhadap gangguan (disturbance) dari blok permintaan aset finansial dibanding disturbance ekonomi lainnya. Walaupun demikian mengingat jasa keuangan terserap hanya sebesar $10.45 \%$ oleh total sektor pertanian, perlu klarifikasi lebih lanjut untuk memastikan kontribusi blok (sektor) permintaan aset finansial ini terhadap blok (sektor) pertanian dengan cara melihat mekanisme transmisi dari blok aset finansial ke blok (sektor) pertanian. Untuk melakukan hal itu model riset ini perlu dimodifikasi dimana variabel-variabel dalam blok pertanian dan blok permintaan aset finansial berada dalam satu VAR. Riset ini belum memungkinkan untuk melakukan hal tersebut karena terbatasnya jumlah series data sampel (ada kendala degree of freedom).

2. Jumlah disequilibrium erroryang signifikan mempengaruhi harga (input dan output pertanian) ternyata lebih besar dibandingkan dengan jumlah disequilibrium error yang mempengaruhi kuantitas (produksi output dan permintaan input). Hal ini mengindikasikan instabilitas dalam sektor pertanian ini lebih terkait oleh guncangan/ perubahan pada harga-harga (input ataupun output) dibanding karena guncangan/ perubahan kuantitas (output ataupun input).

Ketiga, kesimpulan penelitian yang berkaitan dengan inflasi (pergerakan harga output dan pergerakan harga input) adalah sebagai berikut:

1. Inflasi adalah berasal dari sisi suplai, dimana inflasi di sektor pertanian ditentukan oleh harga-harga material pertanian. Temuan ini mengkomfirmasi keberadaan teori cost-push inflation untuk harga pertanian.

2. Harga output hanya mempengaruhi harga material, dan harga material mempunyai kausalitas dua arah dengan upah tenaga kerja mengindikasikan bahwa jika pemerintah ingin menstabilkan sektor pertanian, khususnya kestabilan harga-harga input sektor pertanian akan sangat ditentukan pada keberhasilan pemerintah dalam menstabilkan harga output. 


\section{DAFTAR PUSTAKA}

Engle, R.f. and C.W.J. Granger. 1987. Cointegration and Error Correction: Representation, Estimation and Testing. Review of Economic and Statistics, 64 (2):231-53.

Herliana, L. 2004. Peranan Pertanian dalam Perekonomian Indonesia: Pendekatan Sistem Neraca Sosial Ekonomi dalam Persepektif Structural Path Analysis. Tesis Magister. Sekolah Pascasarjana, Institut Pertanian Bogor, Bogor.

Hutabarat, B. 2001. Investasi Publik pada Sektor Pertanian di Era Otonomi. Forum Agro Ekonomi (FAE), 19(2):24-37.

Johansen, S. 1988. Statistical Analysis of Cointegrating Vectors. Journal of Economic Dynamics and Control, 12(2): 131-154.

Irawan, A. 2004. Analisis Vector Error Correction Model Perilaku PDB Pertanian Indonesia.

Bagian Studi Sektor Riil, Direktorat Riset dan Kebijakan Ekonomi Bank Indonesia, Jakarta.

Simatupang, P dan K. Dermoredjo. 2003. Produksi Domestik Bruto, Harga dan Kemiskinan: Hipotesis Tricle Down Effect dikaji Ulang. Ekonomi dan Keuangan Indonesia (EKI), 51(3):291-324.

Siregar, H. 2002. Empirical Evaluation of Rival Theories of The Business Cycle: Application of Structural VAR Models to New Zealand Economy. Ph.D. Thesis. Lincoln University, Canterbury. and Ward, B. 2002. Were Aggregate Demand Shocks Important in Explaining Indonesian Macro-Economic Fluctuation? Journal of the Asia Pacific Economy, 7(1):35-60.

Sugema, I. 1992. The Dynamic of Macroeconomy-Trade-Agriculture Linkages in The Australian

Economy: An Application of Error Correction Model to Cointegrated Relation Ship. The University of New England. Thesis S2. Department of Agricultural Economic and Business Management, New England.

2000. Indonesia's Deep Economic Crisis: The Role of Tha Banking Sector in Its

Origins and Propagation. A Thesis submitted for Degree of Doctor of Philosophy of The Australian National University.

Syafa'at, N dan Sudi, M. 2002. Identifikasi Sumber Pertumbuhan Output Nasional: Pendekatan Analisis Input-Output. Forum Agro Ekonomi (FAE), 20(1):1-24.

Thomas, R. L. 1999. Modern Econometric. Department of Economics, Manchester Metropolitan University. Addison-Wesley, England.

Verbeek, M. 2002. A Guide to Modern Econometrics. John Wiley and Sons Ltd, England. 


\section{LAMPIRAN IV.A. DAFTAR VARIABEL}

\begin{tabular}{|c|c|c|c|}
\hline \multicolumn{4}{|c|}{ Variabel-variabel dan Data dalam Model Penelitian } \\
\hline \multirow{2}{*}{ BLOK } & \multicolumn{2}{|r|}{ VARIABEL } & \multirow{2}{*}{ DATA } \\
\hline & SIMBOL & KETERANGAN SIMBOL & \\
\hline \multirow{10}{*}{$\begin{array}{l}\text { PERMINTAAN } \\
\text { KOMODITAS }\end{array}$} & LC_BINA & Log nilai Impor Pertanian & $\begin{array}{l}\text { Sumber: CEIC data Company } \\
\text { limited (ribu USA \$) }\end{array}$ \\
\hline & LCBIN_N1 & Log nilai impor non pertanian & $\begin{array}{l}\text { Sumber: CEIC data Company } \\
\text { limited (ribu USA \$) }\end{array}$ \\
\hline & LCA & $\begin{array}{l}\text { Log total Permintaan } \\
\text { komoditas Pertanian }\end{array}$ & $\begin{array}{l}\text { Dihitung PDB pertanian - } \\
\text { Ekspor Pertanian (dalam milyar } \\
\text { rupiah) }\end{array}$ \\
\hline & LCN & $\begin{array}{l}\text { Log total Permintaan } \\
\text { komoditas non pertanian }\end{array}$ & $\begin{array}{l}\text { Dihitung; PDB pertanian - } \\
\text { Ekspor non pertanian } \\
\text { (milyar Rupiah) }\end{array}$ \\
\hline & $\mathrm{LP}_{\mathrm{A}}$ & Log Harga output pertanian. & $\begin{array}{l}\text { Data harga output didekati } \\
\text { dengan Indeks harga } \\
\text { pedagang besar untuk } \\
\text { pertanian }(1983=100) \text {. } \\
\text { Sumber CEIC data Company } \\
\text { Limited }\end{array}$ \\
\hline & $\mathrm{LP}_{\mathrm{N}}$ & Log Harga Ourput Industri & $\begin{array}{l}\text { Indeks Harga Pedagang Besar } \\
\text { Manufaktur } 1983=100\end{array}$ \\
\hline & LREER & $\begin{array}{l}\text { Log Real Effective } \\
\text { Exchange Rate }\end{array}$ & $\begin{array}{l}\text { Sumber: Bagian Analisis dan } \\
\text { Perencanaan Kebijakan } \\
\text { (APK) BI }\end{array}$ \\
\hline & LX & $\begin{array}{l}\text { Log Pengeluaran } \\
\text { konsumsi rumahtangga } \\
\text { domestik }\end{array}$ & $\begin{array}{l}\text { Pengeluaran Konsumsi rumah } \\
\text { tangga (milyar rupiah). Sumber: } \\
\text { International Financial } \\
\text { Statistic (IFS) }\end{array}$ \\
\hline & LPBINA & $\begin{array}{l}\text { Log harga Impor } \\
\text { komoditas pertanian }\end{array}$ & $\begin{array}{l}\text { Didekati dengan Indeks harga } \\
\text { Pedagang besar non migas } \\
(1983=100) \text { sumber CEIC } \\
\text { data Company Limited }\end{array}$ \\
\hline & LPBINN1 & $\begin{array}{l}\text { Log harga Impor Komoditas } \\
\text { non pertanian }\end{array}$ & $\begin{array}{l}\text { Didekati dengan indeks harga } \\
\text { pedagang besar Impor } \\
(1983=100)\end{array}$ \\
\hline
\end{tabular}




\section{Variabel-variabel dan Data dalam Model Penelitian (Lanjutan)}

\begin{tabular}{|c|c|c|c|}
\hline \multirow{2}{*}{ BLOK } & \multicolumn{2}{|c|}{ VARIABEL } & \multirow{2}{*}{ DATA } \\
\hline & SIMBOL & KETERANGAN SIMBOL & \\
\hline \multirow{7}{*}{$\begin{array}{l}\text { PERMINTAAN } \\
\text { ASET }\end{array}$} & LM2 & LOG M2 & $\begin{array}{l}\text { M2. Sumber; Bagian Studi Sektor Riil Bank } \\
\text { Indonesia }\end{array}$ \\
\hline & LPM & $\begin{array}{l}\text { Log implicit price for } \\
\text { holding money } \\
\text { (Harga Implisit } \\
\text { Pemegangan uang) }\end{array}$ & 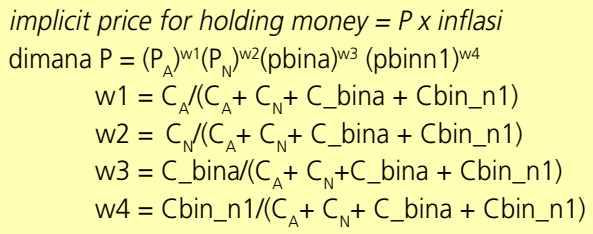 \\
\hline & LPB & $\begin{array}{l}\text { log implicit price for } \\
\text { domestic bonds } \\
\text { (Harga Implisit } \\
\text { Pemegangan Surat } \\
\text { Berharga Domestik) }\end{array}$ & 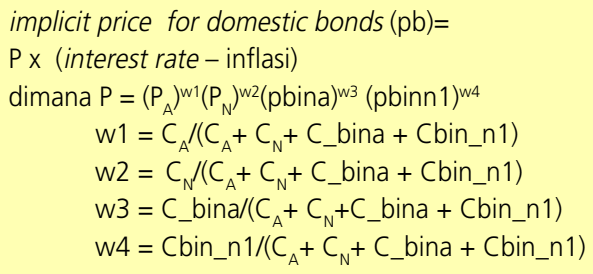 \\
\hline & LPBIN & $\begin{array}{l}\text { log implicit price for } \\
\text { foreign bond (Harga } \\
\text { Implisit Pemegangan } \\
\text { Surat Berharga } \\
\text { Luar Negeri }\end{array}$ & 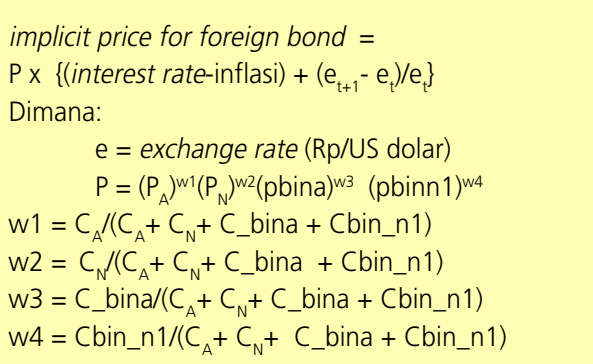 \\
\hline & LW & Log Nominal Wealth & $\begin{array}{l}\text { Nominal Wealth }(\mathrm{W})=(\mathrm{M} 2+\text { Surat Berharga } \\
\text { Domestik (domestic bond })+ \text { Surat Berharga Luar } \\
\text { Negeri (foreign bond /foreign assets) }\end{array}$ \\
\hline & LB & $\begin{array}{l}\text { Log Surat } \\
\text { Berharga (bond) } \\
\text { domestik }\end{array}$ & $\begin{array}{l}\text { Klaim terhadap Pemerintah Pusat dan Sektor Swasta } \\
\text { (Claims on Central Govt. and Private Sektor) } \\
\text { dideflasi dengan harga implisit dari Surat Berharga } \\
\text { (bond) domestik. Sumber: International Financial } \\
\text { Statistic (IFS) }\end{array}$ \\
\hline & LBBIN & $\begin{array}{l}\text { Log Surat Berharga } \\
\text { (bond) Luar negeri }\end{array}$ & $\begin{array}{l}\text { Aset Luar Negeri (Foreign Assets) dideflasi dengan } \\
\text { Harga Implisit dari Surat Berharga (bond) luar negeri }\end{array}$ \\
\hline
\end{tabular}




\section{Variabel-variabel dan Data dalam Model Penelitian (Lanjutan)}

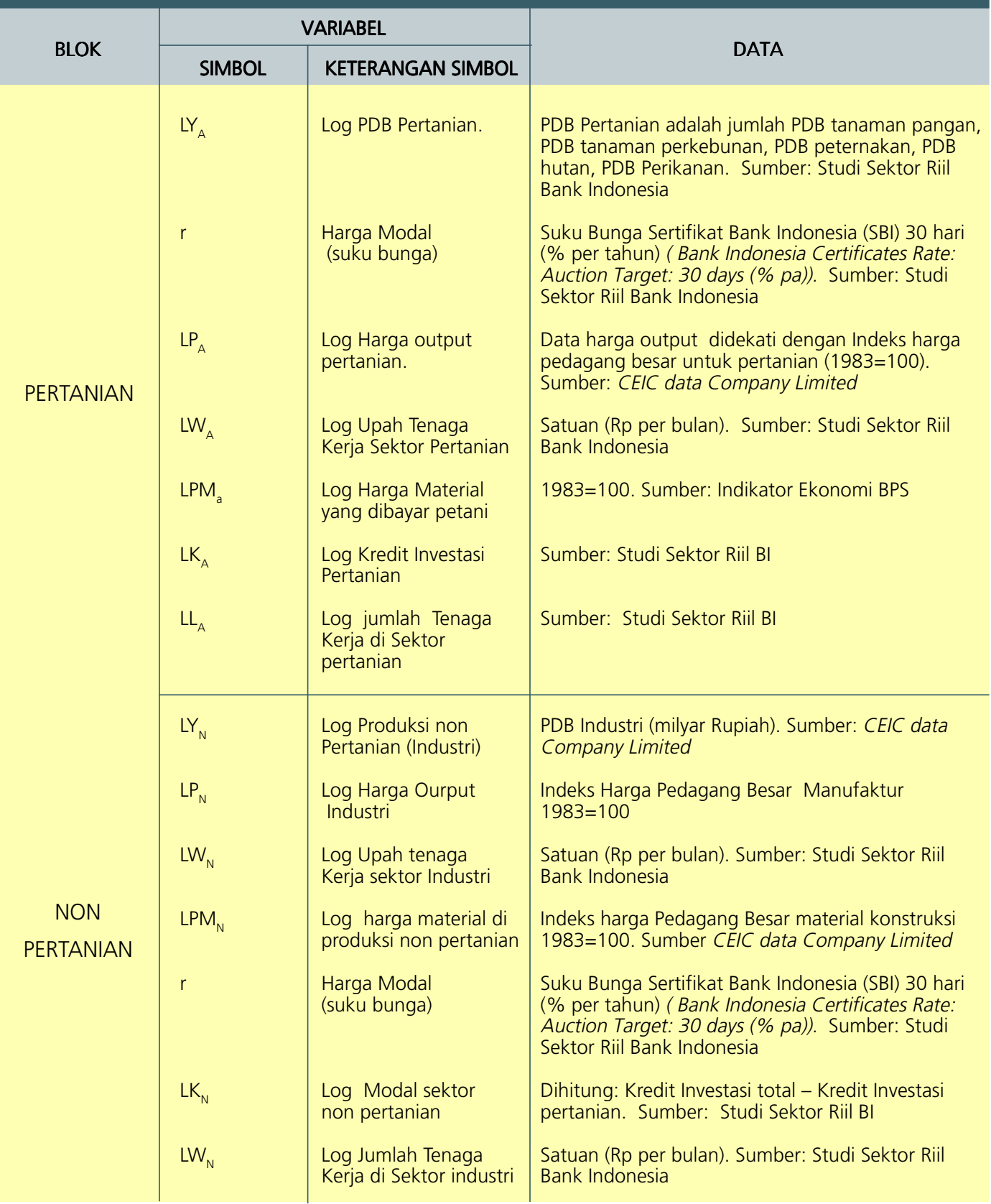




\section{Variabel-variabel dan Data dalam Model Penelitian (Lanjutan)}

\begin{tabular}{|c|c|c|c|}
\hline \multirow{2}{*}{ BLOK } & \multicolumn{2}{|c|}{ VARIABEL } & \multirow{2}{*}{ DATA } \\
\hline & SIMBOL & KETERANGAN SIMBOL & \\
\hline \multirow{6}{*}{$\begin{array}{l}\text { EKSPOR } \\
\text { KOMODITAS }\end{array}$} & LC_A & Log Ekspor Pertanian & $\begin{array}{l}\text { Satuan: \$ USA jutaan Sumber: CEIC data } \\
\text { Company Limited }\end{array}$ \\
\hline & LC_N & $\begin{array}{l}\text { Log Ekpor non } \\
\text { Pertanian }\end{array}$ & $\begin{array}{l}\text { Satuan: \$ USA jutaan. Sumber: CEIC data } \\
\text { Company Limited }\end{array}$ \\
\hline & LP_N & $\begin{array}{l}\text { Log Indeks harga } \\
\text { ekspor non pertanian }\end{array}$ & $\begin{array}{l}\text { Didekati dengan indeks Harga ekspor minyak dan } \\
\text { gas (1983=100). Sumber: CEIC data Company } \\
\text { Limited }\end{array}$ \\
\hline & LP_A & $\begin{array}{l}\text { Log Indeks Harga } \\
\text { ekspor produk } \\
\text { pertanian }\end{array}$ & $\begin{array}{l}\text { Didekati dengan indeks Harga ekspor non migas } \\
(1983=100) \text {. Sumber: CEIC data Company Limited }\end{array}$ \\
\hline & IX_bin & $\begin{array}{l}\text { Log Belanja } \\
\text { konsumsi dunia }\end{array}$ & $\begin{array}{l}\text { Didekati dengan penjumlahan Pengeluaran } \\
\text { Konsumsi rumahtangga Amerika Serikat, Jepang, } \\
\text { Inggris, Australia Hongkong dan Kanada. Sumber: } \\
\text { International Financial Statistic (IFS) }\end{array}$ \\
\hline & LREER & $\begin{array}{l}\text { Log Indeks Real } \\
\text { Effective Exchange Rate }\end{array}$ & $\begin{array}{l}\text { Indeks REER dihitung dengan menggunakan } \\
\text { sekeranjang mata uang dan laju inflasi dari negara } \\
\text { mitra dagang utama (Amerika Serikat, Jepang, } \\
\text { Korea Selatan, Singapura, Jerman, Taiwan, RRC } \\
\text { dan Belanda) dengan memperhitungkan proporsi } \\
\text { perdagangan (ekspor) dan atau impor antara } \\
\text { Indonesia dengan Negara-negara tersebut. Sumber: } \\
\text { Bagian Analisis dan Perencanaan Kebijakan } \\
\text { (APK ) BI }\end{array}$ \\
\hline
\end{tabular}




\section{LAMPIRAN IV.B. PERILAKU MAKSIMISASI KEUNTUNGAN PRODUSEN}

Di dalam pasar komoditas, produsen (perusahaan dan usahatani ) menggunakan tiga jenis input yakni tenaga kerja $(L)$, kapital $(K)$ dan material $(m)$. Anggap fungsi keuntungan tunggal untuk produser ke-i, dimana, dimana $i=A, N(A=$ industri pertanian, $N=$ industri non pertanian)

$$
\begin{aligned}
V\left(K_{i}, L_{i}, m_{i}, K_{i}, t\right)= & \int e^{-\rho(t)}\left[P_{i} F_{i}\left(K_{i}, L_{i}, m_{i}\right)-w L_{i}-P_{m i} m_{i}-\right. \\
& \left.P_{i}\left(\kappa_{i}^{\prime}+\delta K_{i}\right)\right]
\end{aligned}
$$

dimana

$$
\rho(\mathrm{t}) \quad=\int_{0}^{\infty} \mathrm{r}(\mathrm{s}) \mathrm{ds}
$$

Persamaan III.A.1 dapat diekspresikan sebagai berikut:

$$
\text { dimana } g(x, y, z, x, t)=\quad \int_{0}^{\infty} F(x, y, z, x, t) d t
$$

Euler condition untuk persamaan di atas adalah:

$$
\partial f / \partial y=0, \quad \partial f / \partial z=0, \partial f / \partial x=0, \quad \partial f / \partial \chi,=0 ; \quad t \in[0, \infty)
$$

Dengan menggunakan persamaan IV.B.3, kondisi optimal untuk IV.B.1 dapat diturunkan sebagai berikut:

$$
\begin{array}{ll}
\partial f / \partial y=e^{-\rho t)}\left[P_{i} \partial F / \partial L_{i}-W\right]=0 \leftrightarrow \partial F / \partial L_{i}=w / P_{i} & \text { IV.B.4 } \\
\partial f / \partial z=e^{-\rho(t)}\left[P_{i} \partial F / \partial m_{i}-P_{m i}\right]=0 \leftrightarrow \partial F / \partial m_{i}=P_{m_{i}} / P_{i} & \\
\partial f / \partial x=e^{-\rho(t)}\left[P_{i} \partial F / \partial K_{i}-P_{K} \delta\right] & \text { IV.B.5 } \\
\partial f / \partial x=-P_{K} e^{-\rho(t)} \text { dimana } & \rho(t)=\int_{0}^{\infty} r(s) d s
\end{array}
$$

Sehingga dapat diringkas kondisi optimalnya adalah:

$\partial F / \partial L_{i}=W / P_{i}$

$\partial \mathrm{F} / \partial \mathrm{m}_{\mathrm{i}}=\mathrm{P}_{\mathrm{mi}} / \mathrm{P}_{\mathrm{i}}$

$\partial F / \partial K_{i}=P_{K} / P_{i}\left[r+\delta-\left(P_{K} / P_{K}\right)\right]$ 
Fungsi keuntungan dapat diekspresikan sebagai berikut:

$$
\prod_{i}=P_{i} F_{i}\left(K_{i}, L_{i}, m_{i}\right)-w L_{i}-P_{m i} m_{i}-P_{K}\left[r+\delta-\left(P_{K} / P_{K}\right)\right] K_{i}
$$

Persamaan akhirnya adalah:

$$
\begin{aligned}
& L_{i}=f_{L i}\left\{p_{k} / P_{i}, W_{i} / P_{i}, P_{m} / P_{i}, P_{i}\right\} \text { permintaan tenaga kerja IV.B.11 } \\
& \mathrm{K}_{\mathrm{i}}=f_{\mathrm{Ki}}\left\{\mathrm{p}_{\mathrm{K}} / \mathrm{P}_{\mathrm{i}}, \mathrm{w}_{\mathrm{i}} / \mathrm{P}_{\mathrm{i}}, \mathrm{P}_{\mathrm{m}} / \mathrm{P}_{\mathrm{i}}, \mathrm{P}_{\mathrm{i}}\right) \text { Permintaan untuk kapital IV.B.12 } \\
& \mathrm{M}_{\mathrm{i}}=f_{m i}\left\{\mathrm{p}_{\mathrm{k}} / \mathrm{P}_{\mathrm{i}}, \mathrm{w}_{\mathrm{i}} / \mathrm{P}_{\mathrm{i}}, \mathrm{P}_{\mathrm{m}} / \mathrm{P}_{\mathrm{i}}, \mathrm{P}_{\mathrm{i}}\right) \text { Permintaan untuk material IV.B.13 } \\
& Y_{i}=f_{y i}\left\{p_{k} / P_{i}, w_{i} / P_{i}, P_{m} / P_{i}, P_{i}\right) \text { suplai output }
\end{aligned}
$$




\section{LAMPIRAN IV.C. PERILAKU MAKSIMISASI UTILITAS KONSUMEN}

Tujuan dari rumahtangga adalah memaksimisasikan utilitas selama total waktu hidup mereka (its total lifetime utility) dengan kendala ketersediaan anggaran antar waktu (intertemporal budget constraint). Peran rumahtangga dalam perekonomian adalah membuat rencana dan keputusan yang berkaitan dengan konsumsi saat ini (present) dan yang akan datang (future) serta pemegangan aset (assets holdings). Diasumsikan bahwa utilitas direpresentasikan dengan fungsi utilitas tunggal (single utiliity function). Fungs konsumsi dan permintaan aset yang mana bereasal dari masalah maksimisasi rumahtangga menunjukkan arti penting dari kekayaan (wealth) dan ekspetasi dari harga aset di masa depan (future asset prices) serta suku bunga sebagai penentu dari perilaku rumahtangga. Rencana rumahtangga sekarang (current plans) melahirkan permintaan konsumsi, money, saham (equities) dan leisure. Dengan demikian fungsi utilitas terdiri dari leisure, barang-barang konsumsi, pemegangan aset (asset holding). Fungsi utilitas lifetime dapat dinyatakan sebagai berikut:

$$
V=\int_{0}^{\infty} e^{-s t} U\left(H, C_{A^{\prime}} C_{N^{\prime}} C \_B I N A, C B I N \_N 1, M / P, B / P, \overline{e B B I N} / p\right) d t \quad \text { IV.C.1 }
$$

Sedangkan Kendala anggaran dapat dinyatakan sebagai berikut:

$$
\left.\mathrm{P}_{\mathrm{A}} \mathrm{C}_{\mathrm{A}}+\mathrm{P}_{\mathrm{N}} \mathrm{C}_{\mathrm{N}}+\overline{\mathrm{e}} \text { (PBINA C_BINA + PBINN1 CBIN_N1 }+\mathrm{BBIN}\right)+\mathrm{M}+\mathrm{B}=\mathrm{WL}+\mathrm{rB}+\overline{\mathrm{e}}{ }^{*} \mathrm{BBIN}
$$

Bentuk Hamiltonnian dari persamaan di atas adalah:

$$
\begin{aligned}
& \text { maks }=\int_{0}^{\infty} e^{-s t} U(.) d t+\lambda\left\{w L+r B+\bar{e} r * B B I N-\left(P_{A} C_{A}+P_{N} C_{N}+\right.\right. \\
& \overline{\mathrm{e}}(\mathrm{PBINA} \text { C_BINA* + PBINN1 CBIN_N1 + BBIN) }+\mathrm{M}+\mathrm{B}\} \quad \text { IV.C.2 } \\
& \mathrm{L} \quad: \mathrm{e}^{-\mathrm{st}}\{\lambda \mathrm{W}-\partial \mathrm{U} / \partial \mathrm{L}\}=0 \leftrightarrow \partial \mathrm{U} / \partial \mathrm{L}=\lambda \mathrm{W} \quad \text { IV.C.3 } \\
& C_{A}: e^{-s t}\left\{\lambda P_{A}-\partial U / \partial C_{A}\right\}=0 \leftrightarrow \partial U / \partial C_{A}=\lambda P_{A} \quad \text { IV.C.4 } \\
& C_{N}: e^{-s t}\left\{\lambda P_{N}-\partial U / \partial C_{N}\right\}=0 \leftrightarrow \partial U / \partial C_{N}=\lambda P_{N} \quad \text { IV.C.5 } \\
& \text { C_BINA: } e^{-s t}\left\{\lambda \bar{e} P B I N A-\left(\partial U / \partial C \_B I N A\right)\right\}=0 \\
& \leftrightarrow \partial \mathrm{U} / \partial \mathrm{C} \_\mathrm{BINA}=\lambda \overline{\mathrm{e}} \mathrm{PBINA} \quad \text { IV.C.6 } \\
& \text { CBIN_N1: } e^{-s t}\left\{\lambda \bar{e} \text { PBINN1 }-\left(\partial U / \partial C B I N \_N 1\right)\right\}=0 \\
& \leftrightarrow \quad \partial \mathrm{U} / \partial \mathrm{CBIN} \_\mathrm{N} 1=\lambda \overline{\mathrm{ePBINN}} 1 \quad \text { IV.C.7 } \\
& \text { M : } e^{-s t}\{(I / P) \cdot[\partial U / \partial(M / P)]\}=d / d t\left[e^{-s t}(-\lambda)\right]=s \lambda-e^{-s t} \lambda \text {. } \\
& \leftrightarrow[\partial \mathrm{U} / \partial(\mathrm{M} / \mathrm{P})]=\mathrm{P} \lambda[\mathrm{s}-(\lambda / \lambda)] \quad \text { IV.C.8 } \\
& B: e^{-s t}\{(I / P) \cdot[\partial U / \partial(B / P)]+r \lambda\}=d / d t\left[e^{-s t}(-\lambda)\right]=e^{-s t}(s \lambda)-e^{-s t} \lambda \text {. }
\end{aligned}
$$




$$
\leftrightarrow \quad[\partial \mathrm{U} / \partial(\mathrm{B} / \mathrm{P})]=\mathrm{P} \lambda[s-r-(\lambda / \lambda)]
$$

BBIN : $e^{-s t}\{(I / P) \cdot[\partial U / \partial(\bar{e} B B I N / P)]+\bar{e} r \star \lambda\}=d / d t\left[e^{-s t}(-\lambda \bar{e})\right]=e^{-s t}(s \lambda)-e^{-s t} \lambda$.

$\leftrightarrow[\partial \mathrm{U} / \partial(\overline{\mathrm{e}} \mathrm{B} / \mathrm{P})]=\mathrm{P} \lambda\left[s-r^{*}-\overline{\mathrm{e}} \cdot / \overline{\mathrm{e}}-(\lambda / \lambda)\right]$

Bentuk umum dari first order condition adalah:

$$
\partial \mathrm{U}(.) / \partial \mathrm{X}_{\mathrm{i}}=\lambda \mathrm{P}_{\mathrm{i}}
$$

dimana $X_{i}$ adalah $C_{A^{\prime}} C_{N^{\prime}}$ C_BINA, CBIN_N1, M, B, BBIN dan L

Harga implisit untuk leisure dan aset finansial dapat diturunkan sebagai berikut:

$\mathrm{P}_{\mathrm{H}}=\mathrm{W} \quad$ harga implicit untuk leisure

$P_{M}=P[s-(-\pi)]$ harga implisit untuk pemegangan uang

$P_{B}=P[s-(r-\pi)]$ harga implisit untuk domestic bonds

$\mathrm{PBIN}=\mathrm{P}\left[\mathrm{s}-\left(\mathrm{r}^{*}-\pi+\dot{\mathrm{e}} / \overline{\mathrm{e}}\right)\right]$ harga implisit untuk foreign bond

IV.C.15

Dengan demikian fungsi permintaan komoditas dapat diformulasikan sebagai berikut:

Permintaan optimal untuk komoditas domestik ke-i

$$
\begin{array}{ll}
C_{A}= & C_{A}\left(P_{A^{\prime}} P_{N^{\prime}} \text { ë PBINA, ē PBINN } 1 ; X\right) \\
C_{N}= & C_{N}\left(P_{A^{\prime}} P_{N^{\prime}} \text { ē PBINA, ē PBINN } 1 ; X\right)
\end{array}
$$

Permintaan optimal untuk barang impor

$$
\begin{aligned}
& \text { C_BINA }=C_{-B I N A}\left(P_{A^{\prime}} P_{N^{\prime}} \bar{e} \text { PBINA, éPBINN1; } X\right) \\
& \text { CBIN_N1 }=C_{B I N \_N 1}\left(P_{A^{\prime}}, P_{N^{\prime}} \bar{e} \text { PBINA, ēPBINN1; } X\right)
\end{aligned}
$$

Dimana $X=C_{A}+C_{N}+C \_B I N A+C B I N \_N 1=$ total pengeluaran

Sedangkan fungsi permintaan aset finansial adalah sebagai berikut:

Permintaan optimal untuk uang

$$
\mathrm{M}=f_{M}\left(\mathrm{P}_{\mathrm{M}^{\prime}} \mathrm{P}_{\mathrm{B}^{\prime}} \mathrm{PBIN} ; \mathrm{W}\right)
$$

Permintaan optimal untuk saham domestik (domestic bonds)

$$
B=f_{B}\left(P_{M^{\prime}}, P_{B}, P B I N ; W\right)
$$

Permintaan optimal untuksaham asing (foreign bonds)

$$
\mathrm{BBIN}=f_{B B I N}\left(\mathrm{P}_{\mathrm{M}^{\prime}}, \mathrm{P}_{\mathrm{B}^{\prime}}, \mathrm{PBIN} \mathrm{N}_{\mathrm{B}^{\prime}} ; \mathrm{W}\right)
$$

Dimana $\mathrm{W}=\mathrm{M}+\mathrm{B}+\mathrm{BBIN}=$ kekayaan nominal

$X=$ belanja total (expenditure total)

$\mathrm{W}=$ kekayaan nominal (nimonal wealth) 


\section{LAMPIRAN IV.D. PERMINTAAN EKSPOR}

Permintaan ekspor diturunkan dari fungsi utilitas intertemporal dari rumahtangga di dalam ekonomi luar negeri. Prinsip dari penurunan sama dengan proses penurunan pada perilaku rumahtangga domestik. Fungsi utilitas rumahtangga luar negeri tersusun atas leisure, konsumsi komoditas, dan pemegangan aset. Fungsi utilitas sepanjang hidup (the lifetime utility function) dapat dinyatakan sebagai berikut:

$$
V=\int_{0}^{\infty} e^{-s t} U\left(H, C_{-A^{\prime}} C_{-N^{\prime}} C^{*}{ }_{-A^{\prime}} C_{-N^{*}}, M^{*} / P^{*}, B_{-}^{*} / P^{*}, \bar{e}_{-} / P^{*}\right) d t \quad \text { IV.D.1 }
$$

Tanda subskrip ( _ ) menunjukkan variabel yang bersangkutan menunjukkan konsumsi dari dari komponen luar negeri. Sedangkan kendala anggaran terhadap fungsi utilitas di atas dapat dinyatakan sebagai berikut:

$$
\left.\mathrm{e}\left(\mathrm{P}_{-A} \mathrm{C}_{-A}+\mathrm{P}_{-N} \mathrm{C}_{-N}+\mathrm{B}_{-}\right)+\mathrm{P}^{*}{ }_{-A} \mathrm{C}^{*}{ }_{-A}+\mathrm{P}_{-}{ }^{*} \mathrm{C}_{-}{ }_{-}{ }_{N}+\mathrm{M}^{*}+\mathrm{B}^{*}\right)=\mathrm{w}^{*} L^{*}+\mathrm{er} \mathrm{B}_{-}+\mathrm{r}^{*} \mathrm{~B}_{-}
$$

Bentuk Hamiltonnian dari persamaan di atas adalah:

$$
\begin{array}{rlrl}
\text { maks }= & \int_{0}^{\infty} e^{-s t} U_{-}(.) d t+{ }_{-}\left\{w^{*} L^{*}+e r B_{-}+r^{*} B_{-}{ }^{*}-\left(P^{*}{ }_{-A} C^{*}{ }_{-A}+P^{*}{ }_{-N} C^{*}{ }_{-N}+\right.\right. \\
& \left.e\left(P_{-A} C_{-A}+P_{-N} C_{-N}+B\right)+M^{*}+B^{*}\right\} & \text { IV.D. } 2
\end{array}
$$

Bentuk umum dari first order condition adalah:

$$
\begin{aligned}
& \partial U_{-}(.) / \partial X_{i}=\lambda P_{i} \\
& \text { dimana } X_{i} \text { adalah } C_{-A^{\prime}} C_{-N^{\prime}} C^{*}{ }_{-A^{\prime}} C^{*}{ }_{-N^{\prime}} M^{*}, B_{-}{ }^{*}, B_{-} \text {dan } L^{*}
\end{aligned}
$$

First order condition untuk permintaan ekspor yang optimal adalah:

$$
\begin{array}{llll}
C_{-A} & : e^{-s t}\left\{\lambda e_{-A}-\partial U_{-} / \partial C_{-A}\right\}=0 \leftrightarrow \partial U_{-} / \partial C_{-A}=\lambda e P_{-A} & \text { IV.D. } 4 \\
C_{-N} & : e^{-s t}\left\{\lambda e_{-N}-\partial U_{-} / \partial C_{-N}\right\}=0 \leftrightarrow \partial U_{-} / \partial C_{-N}=\lambda P_{-N} & \text { IV.D. } 5
\end{array}
$$

Dengan demikian permintaan ekspor untuk komoditas ke-i dapat diformulasikan sebagai berikut; $C_{-i}=C_{-i}\left(e P_{-A^{\prime}} e P_{-N^{\prime}} P_{-A}{ }^{*}, P_{-N}{ }^{*} ; X^{*}\right) \quad$ IV.D.6 
halaman ini sengaja dikosongkan 